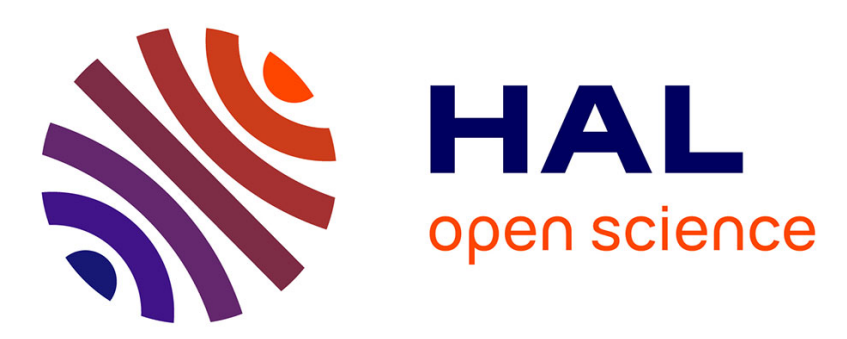

\title{
Carbon dioxide, methane and nitrous oxide emissions from the human-impacted Seine watershed in France
}

\author{
Audrey Marescaux, Vincent Thieu, Josette Garnier
}

\section{To cite this version:}

Audrey Marescaux, Vincent Thieu, Josette Garnier. Carbon dioxide, methane and nitrous oxide emissions from the human-impacted Seine watershed in France. Science of the Total Environment, 2018, 643, pp.247-259. 10.1016/j.scitotenv.2018.06.151 . hal-01919638

\section{HAL Id: hal-01919638 \\ https://hal.sorbonne-universite.fr/hal-01919638}

Submitted on 12 Nov 2018

HAL is a multi-disciplinary open access archive for the deposit and dissemination of scientific research documents, whether they are published or not. The documents may come from teaching and research institutions in France or abroad, or from public or private research centers.
L'archive ouverte pluridisciplinaire HAL, est destinée au dépôt et à la diffusion de documents scientifiques de niveau recherche, publiés ou non, émanant des établissements d'enseignement et de recherche français ou étrangers, des laboratoires publics ou privés. 


\title{
Carbon dioxide, methane and nitrous oxide emissions from the human-impacted Seine watershed in France
}

\author{
Audrey Marescaux ${ }^{1}$, Vincent Thieu ${ }^{1}$, Josette Garnier ${ }^{1}$ \\ ${ }^{1}$ Sorbonne Université, CNRS, Institut Pierre Simon Laplace, UMR 7619 METIS, Paris, France
}

Marescaux, A., Thieu, V. and Garnier, J.: Carbon dioxide, methane and nitrous oxide emissions from the human-impacted Seine watershed in France. Science of the Total Environment, 643, 247-259 (2018). doi: 10.1016/j.scitotenv.2018.06.151

https://www.sciencedirect.com/science/article/pii/S0048969718322277?via\%3Dihub 


\section{Graphical abstract}

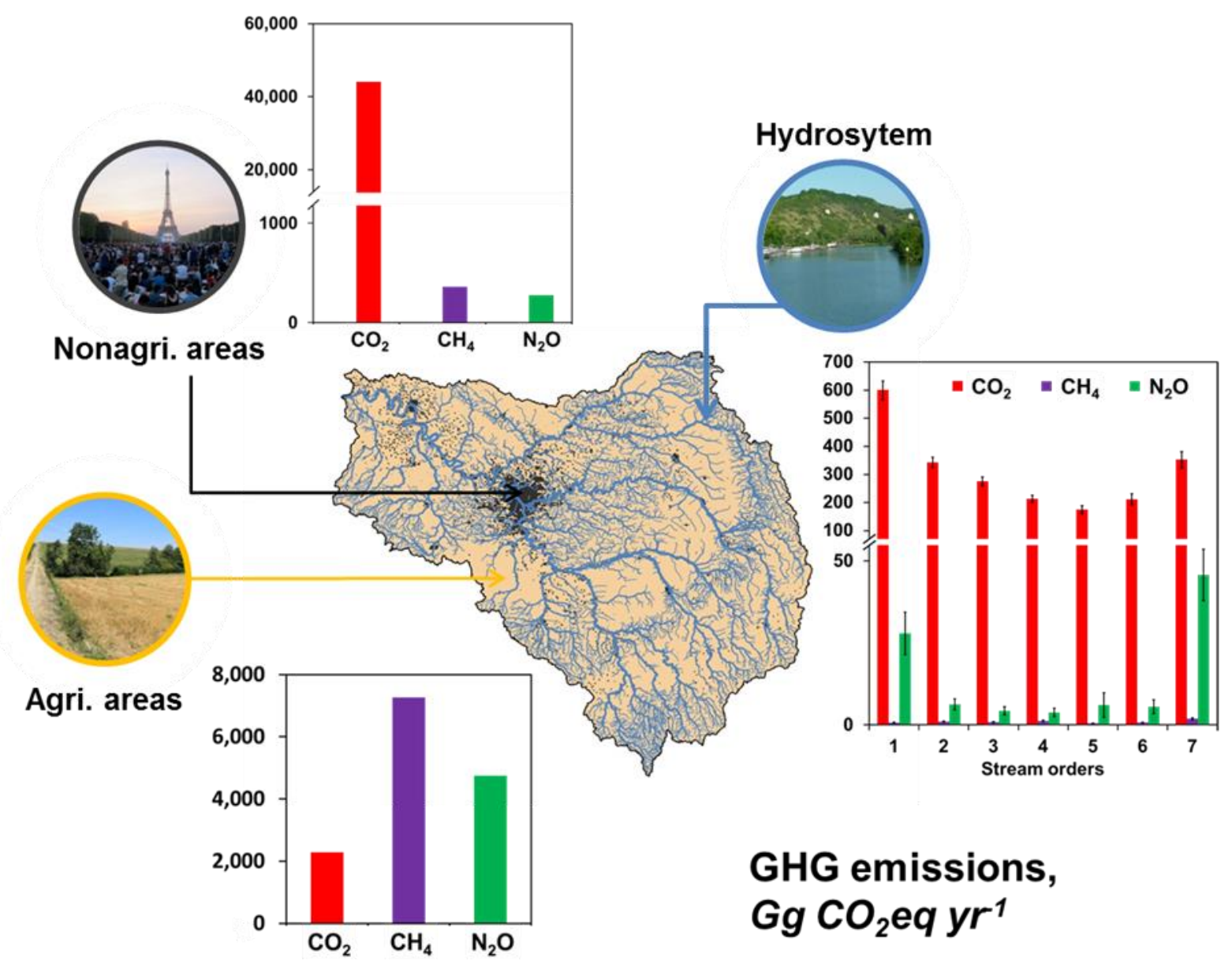




\begin{abstract}
Greenhouse gas (GHG) emissions from rivers and lakes have been shown to contribute significantly to global carbon and nitrogen cycling. In temperate and human-impacted regions, simultaneous carbon dioxide, methane and nitrous oxide emissions from aquatic systems are poorly documented. We estimated carbon dioxide $\left(\mathrm{CO}_{2}\right)$ concentrations in the Seine hydrosystem $\left(71,730 \mathrm{~km}^{2}\right.$, France) using direct measurements in 14 field campaigns conducted between 2010 and 2017, and calculations of $\mathrm{CO}_{2}$ partial pressures compared with methane $\left(\mathrm{CH}_{4}\right)$ and nitrous oxide $\left(\mathrm{N}_{2} \mathrm{O}\right)$ concentrations.

In the main stem of the Seine River, $\mathrm{CO}_{2}$ showed the same spatial gradient as $\mathrm{N}_{2} \mathrm{O}$ and $\mathrm{CH}_{4}$ with peaks in concentration downstream from the arrival of effluents from wastewater treatment plants enriched in organic matter, thus favoring mineralization. It is likely that high $\mathrm{CO}_{2}$ concentrations upstream were due to organic carbon inputs from soils and enriched $\mathrm{CO}_{2}$ groundwater discharges, whereas high $\mathrm{N}_{2} \mathrm{O}$ and $\mathrm{CH}_{4}$ upstream values were likely due to denitrification in riparian wet areas and anoxic decomposition of organic matter-rich wetlands, respectively. In addition, seasonal variations in all three GHGs were observed with higher concentrations in summer when higher temperatures promote mineralization and low water reduces the dilution of organic matter mainly originating from WWTP effluents.
\end{abstract}

GHG emissions were calculated and compared with agricultural and nonagricultural (urban, transport) fluxes in the basin. In the Seine River network, $\mathrm{CO}_{2}$ emissions dominated riverine GHG emissions, reaching 95.3\%, while $\mathrm{N}_{2} \mathrm{O}$ and $\mathrm{CH}_{4}$ emissions accounted for $4.4 \%$ and $0.3 \%$, respectively. These indirect emissions from the hydrosystem were estimated to account for $3.7 \%$ of the total GHG emissions from the basin that amounted to $61,284 \mathrm{Gg} \mathrm{CO}_{2} \mathrm{eq} \mathrm{yr}^{-1}$. Comparatively, direct agricultural and nonagricultural GHG emissions were estimated at $23.3 \%$ and $73.0 \%$., respectively.

Keywords: Seine Basin; CO2; CH4; N2O; direct/indirect emissions; human impacts 


\subsection{Introduction}

Carbon dioxide $\left(\mathrm{CO}_{2}\right)$, methane $\left(\mathrm{CH}_{4}\right)$ and nitrous oxide $\left(\mathrm{N}_{2} \mathrm{O}\right)$ have been shown to dominate the well-mixed greenhouse gases (GHGs), contributing $80 \%$ of the positive radiative forcing driving climate change (Myhre et al., 2013). Between 1750, the beginning of the Western industrial revolution, and 2011, atmospheric concentrations of $\mathrm{CO}_{2}, \mathrm{CH}_{4}$ and $\mathrm{N}_{2} \mathrm{O}$ increased by $40 \%, 150 \%$ and $20 \%$, respectively, reaching values of $390.5 \mathrm{ppm}( \pm 0.2 \mathrm{ppm}), 1803.2 \mathrm{ppm}$ $( \pm 0.2 \mathrm{ppm})$ and $324.2 \mathrm{ppb}( \pm 0.2 \mathrm{ppb})$ (Hartmann et al., 2013).

For the 1750-2011 period, anthropogenic $\mathrm{CO}_{2}$ emissions at the global scale reached 555,000 \pm 85 teragrams of carbon $(\mathrm{TgC})$. Fossil fuel combustion and cement production were responsible for $67.5 \%$ of it while land use change accounted for $32.4 \%$ (Almajhdi et al., 2013). For the 2000-2009 period, anthropogenic $\mathrm{CH}_{4}$ global emissions were estimated at 248 (228-276368) $\mathrm{TgC}^{-\mathrm{CH}_{4}} \mathrm{yr}^{-1}$ (bottom-up approach) (Almajhdi et al., 2013). The Intergovernmental Panel on Climate Change (IPCC) report (2013), attributed $60.4 \%$ of $\mathrm{CH}_{4}$ sources to agriculture and waste, $10.6 \%$ to biomass and biofuel burning and $29 \%$ to fossil fuel combustion. $\mathrm{N}_{2} \mathrm{O}$ atmospheric concentrations have also increased considerably since the preindustrial era, due to intensification of agriculture and the use of synthetic nitrogen $(\mathrm{N})$ fertilizers and manure applications that increased the production of $\mathrm{N}_{2} \mathrm{O}$ in soils, sediments and aquatic ecosystems. In addition to fertilization, industrial processes (e.g., manufacture of nylon), effluents from wastewater treatment, cattle feedlots and excrement, biomass burning and land emissions due to atmospheric nitrogen deposition (from agriculture, fossil fuel combustion, burning biomass and industrial activities) also contributed to an increase in $\mathrm{N}_{2} \mathrm{O}$ emissions of 6.9 (2.7-11.1) $\left.\mathrm{TgN}_{(\mathrm{N}} \mathrm{O}\right) \mathrm{yr}^{-1}$ over the last two decades (Seitzinger et al. 2000; Khalil et al. 2002; Ciais et al., 2013).

Global emissions of these three GHGs from streams and rivers have been reported in the literature as important fluxes in the continental GHG budgets. $\mathrm{CO}_{2}$ emissions from rivers and

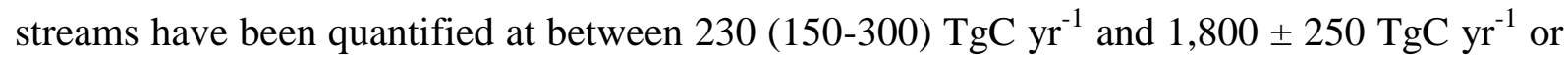

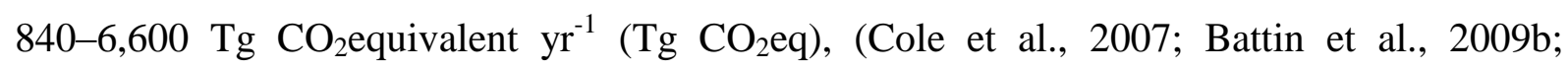
Aufdenkampe et al., 2011; Lauerwald et al., 2015; Regnier et al., 2013; Raymond et al., 2013a ; Sawakuchi et al., 2017; Drake et al., 2017). $\mathrm{CH}_{4}$ global inland water emissions have

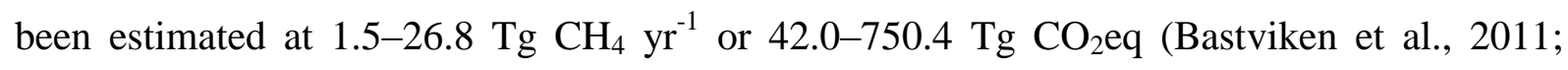


Sawakuchi et al. 2014; Borges et al. 2015; Stanley et al. 2016) while $\mathrm{N}_{2} \mathrm{O}$ riverine emissions

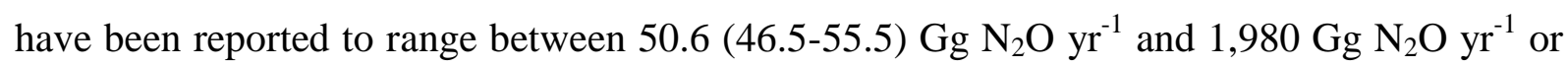
13.4 Tg $\mathrm{CO}_{2}$ eq and 524.7 $\mathrm{Tg} \mathrm{CO}_{2}$ eq (Kroeze et al., 2010; Beaulieu et al., 2011; Hu et al., 2016). In $\mathrm{CO}_{2} \mathrm{eq}$, global $\mathrm{CO}_{2}$ emissions are about ten times higher than $\mathrm{CH}_{4}$ and $\mathrm{N}_{2} \mathrm{O}$ emissions. Many regional studies on inland waters have proposed a specific focus on $\mathrm{CO}_{2}$ emissions (Butman and Raymond 2011; Denfeld et al. 2013; Abril et al. 2014; Ran et al., 2017, van Geldern et al., 2015, among others), $\mathrm{CH}_{4}$ emissions (e.g., Bastviken et al. 2004; Garnier et al., 2013; Sawakuchi et al., 2014; Spawn et al. 2015; McGinnis et al. 2016) or $\mathrm{N}_{2} \mathrm{O}$ emissions (e.g., Seitzinger et al. 2000; Garnier et al., 2009; Yu et al., 2013; Turner et al., 2015). However, only a few studies have assessed the three GHG concentrations together or emissions from lentic ecosystems (reservoirs and lakes) (e.g., Huttunen et al., 2003; Zhao et al., 2013; Miettinen et al., 2015; Huang et al. 2015; Wang et al. 2017) or from streams and rivers (e.g., Harrison et al., 2005; Hlaváčová et al., 2006; Borges et al., 2015; Teodoru et al., 2015; Schade et al., 2016; Borges et al., 2018).

Anthropogenic activities are known to have marked impacts on biogeochemical cycles and on $\mathrm{CO}_{2}, \mathrm{CH}_{4}$ and $\mathrm{N}_{2} \mathrm{O}$ emissions (e.g., Kempe, 1982 and 1984; Seitzinger et al., 2000; Garnier et al., 2007; Rajkumar et al., 2008; Barros et al., 2011; Baulch et al., 2011; Regnier et al., 2013; Alshboul et al., 2016b; Deemer et al., 2016; Martinez-Cruz et al., 2017; Prairie et al., 2017). $\mathrm{N}_{2} \mathrm{O}$ emissions from the highly urbanized Seine drainage network have been estimated at 0.10-0.20 gigagrams $(\mathrm{Gg}) \mathrm{N}-\mathrm{N}_{2} \mathrm{O} \mathrm{yr}^{-1}$ or $42-83 \mathrm{Gg} \mathrm{CO}_{2} \mathrm{eq} \mathrm{yr}^{-1}$ (Garnier et al. 2009), while $\mathrm{CH}_{4}$ emissions have been estimated at $0.30 \mathrm{GgC}_{-} \mathrm{CH} 4 \mathrm{yr}^{-1}$ or $11.2 \mathrm{Gg} \mathrm{CO}_{2} \mathrm{eq} \mathrm{yr}^{-1}$ (Garnier et al., 2013b). $\mathrm{CO}_{2}$ emissions from the Seine basin have not yet been investigated, apart from occasional values of $\mathrm{pCO}_{2}$ calculated in the Seine at Paris (annual mean for 1975-1979: 1997 ppmv; Kempe, 1982). Nevertheless, comparison of the three GHG budgets at the global scale (with a factor of 10 between $\mathrm{CO}_{2}$ and $\mathrm{N}_{2} \mathrm{O}$ or $\mathrm{CH}_{4}$ emissions expressed in $\mathrm{CO}_{2}$ eq), supports the hypothesis that $\mathrm{CO}_{2}$ emissions could also account for a large proportion of the GHG emissions at the regional scale of a single watershed.

This paper compares GHG behaviors $\left(\mathrm{CO}_{2}, \mathrm{CH}_{4}, \mathrm{~N}_{2} \mathrm{O}\right)$ in the Seine River, a temperate hydrosystem subjected to strong anthropogenic pressures and quantifies the emissions from the drainage network. Earlier papers by our team already examined water concentrations and emissions of $\mathrm{N}_{2} \mathrm{O}$ (Garnier et al., 2009) and $\mathrm{CH}_{4}$ (Garnier et al., 2013). Here we report on new 
field investigations to examine $\mathrm{pCO}_{2}$ and $\mathrm{CO}_{2}$ emissions together with $\mathrm{CH}_{4}$ and $\mathrm{N}_{2} \mathrm{O}$. Spacetime analyses at the scale of the Seine River basin using this unique GHG data set were expected to provide new insights into GHG riverine emissions, particularly the impact of wastewater effluents from the Parisian conurbation (12 M inhabitants). The second aim of this study was to compare the indirect emissions from the drainage network with estimated direct emissions from land under different uses (croplands, grasslands and forests, and livestock farming) and due to other activities (energy transformation, industry, residential and tertiary sectors, as well as transport) using existing data, in order to identify the main sources of emissions.

\subsection{Material and methods}

\subsubsection{Study site}

The Seine River is located in the north of France with a catchment of approximately 71,730 $\mathrm{km}^{2}$ at Poses, where a weir separates the river from its estuary, and flows into the English Channel. Its average annual discharge over the past 10 years at the outlet is $500 \mathrm{~m}^{3} \mathrm{~s}^{-1}$ (French water authorities Agence de l'Eau Seine Normandie - French acronym AESN, http://www.eau-seine-normandie.fr/, last accessed 2018/11/05). The Seine basin is densely populated (> 200 inhabitants (inhab.) $\mathrm{km}^{-2}$ for the basin as a whole but reaching more than 20,000 inhab. $\mathrm{km}^{-2}$ in inner Paris and around 5,000-7,000 inhab. $\mathrm{km}^{-2}$ in the Paris conurbation) (Fig. 1) (INSEE 2013). Heavily urbanized and industrialized in its downstream sector, the upstream basin is dominated by croplands.

The Seine River watershed can be represented by the Strahler stream order (SOs) (Strahler, 1952; 1957) a concept describing any hydrological network from its source (SO 1) to its estuary by a regular pattern of confluence of tributaries with increasing stream order. The Seine hydrological network is represented by more than 3,000 first SOs to one SO 7 (the lower Seine river) (Annex 1-1). The main stem studied here is the downstream Marne River (SO 6) and the lower Seine (SO 7). The Marne River basin is intensively cropped and densely populated in its downstream sector and used to be one of the most eutrophic rivers of the drainage network (Garnier et al., 2005) (Fig. 1). The Marne joins the Seine River at the entrance of Paris. Downstream from Paris, the Seine River receives the treated effluents of 12 
million inhabitants, strongly impacting the lower Seine River, downstream from the confluence with the Oise River (SO 6). The main land use classes in the basin are croplands (56.8\% of the basin), forests (25.8\%) and grasslands (9.7\%), urbanized areas represent $7.0 \%$ (CLC database, IFEN, 2006) and wetlands (between 10.9\%-15.6\%; Curie et al., 2007). The lithology of the sedimentary basin of the Seine River is dominated by chalk, limestone and carbonates (Annex 1-1).

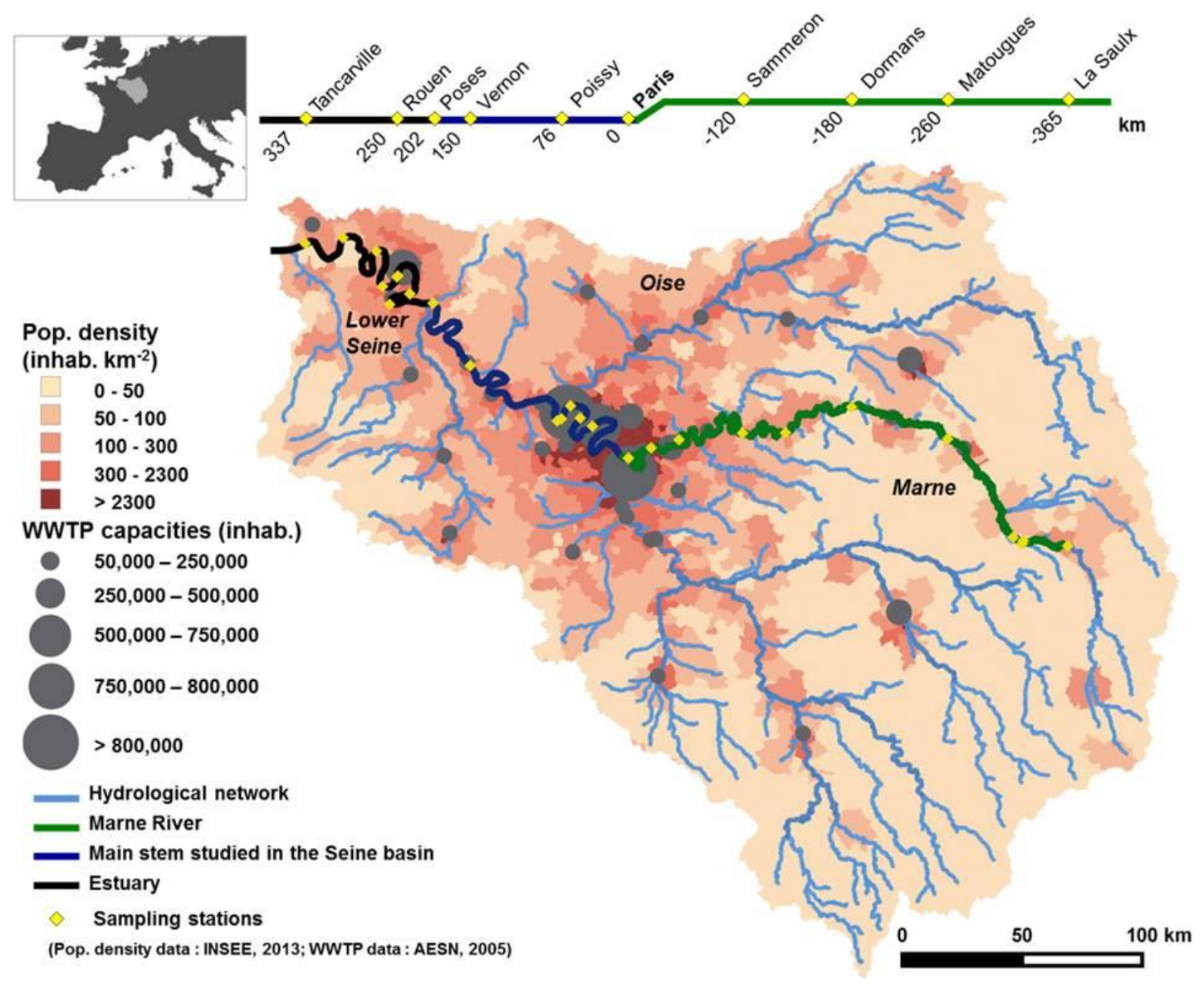

Fig. 1 Population density and main wastewater treatment plant capacities of the Seine River watershed (France) (INSEE, 2013 and the French water authorities - AESN 2005). In yellow, measurement stations located along the main stem of the Seine River (Marne River and the lower Seine) were sampled in 2010 (May 3-4; July 5-7; October 2-6 2010) in 2011 (May 17-19; August 23-28), in 2012 (April 4-10; August 28 to September 3), in 2013 (February 13-18; June 17-23 2013) and 2014 (May 13-17; September 9-12). One of the main stems of the Seine River is shown at the top of the figure with sampling stations and distance from Paris in kilometers $(\mathrm{km}=0)$. 


\subsubsection{Sampling strategies}

Eleven field campaigns were conducted at 23 sampling locations over a distance of $700 \mathrm{~km}$ (exact locations in Annex 1-6). Sampling sites were selected to account for the spatial variability of the upstream basin along the Marne River, upstream and downstream from the main WWTPs, including Paris, and along the lower Seine. The 11 field campaigns at low water were conducted in 2010 (May 3-4 May; July 5-7; October 2-6 2010), in 2011 (May 17-19; August 23-28), in 2012 (April 4-10; August 28 to September 3), in 2013 (February 13-18; June 17-23 2013), and in 2014 (May 13-17; September 9-12). In addition to these longitudinal profiles, smaller SOs were sampled during two snap-shot campaigns in 2016 (February 22 to March 10, and September 7-14) and one in 2017 (March 14-23). A total of 14 campaigns are therefore analyzed here. Sampling locations covered all important land use classes in the basin.

In the field, $100 \mathrm{ml}$ borosilicate serum bottles were filled with water without air to determine $\mathrm{N}_{2} \mathrm{O}$ and $\mathrm{CH}_{4}$ levels. To stop biological processes and gas exchange, $50 \mu \mathrm{l}$ of $\mathrm{HgCl}_{2}(2 \%)$ was added to the bottles that were then sealed with a rubber septum. In addition, 2-1 water chemistry sampling bottles (high-density polyethylene) were filled and $\mathrm{pH}$ (NBS scale), water temperature, turbidity, dissolved oxygen and conductivity variables were measured using a multiparameter instrument (YSI® 6600 V2). Buffers ( $\mathrm{pH} 4$ and 7) were used for $\mathrm{pH}$ calibration, potassium chloride electrolyte solution for dissolved oxygen, and $10 \mathrm{mS} \mathrm{cm} \mathrm{cm}^{-1}$ standard for conductivity.

In the laboratory, total alkalinity (TA) $\left(\mu \mathrm{mol} \mathrm{kg}{ }^{-1}\right)$ was analyzed using three replicates of 20 $\mathrm{ml}$ of filtered water $(\mathrm{GF} / \mathrm{F}: 0.7 \mu \mathrm{m})$ with an automatic titrator (TitroLine ${ }^{\circledR} 5000$ ) and $\mathrm{HCl}$ 0.1M. Dissolved nitrate and ammonium were determined on filtered water $(\mathrm{GF} / \mathrm{F}, 0.7 \mu \mathrm{m})$ with an automated analyzer (Gallery ${ }^{\mathrm{TM}}$ Automated Photometric Analyzer) according to Jones (1984) and Slawyk and MacIsaac (1972), respectively.

For dissolved organic carbon (DOC), analyses were collected in glass flasks after filtration on $\mathrm{GF} / \mathrm{F}$ Whatman grilled filters (GF/F, $0.7 \mu \mathrm{m}$ porosity, at $500^{\circ} \mathrm{C}$ for $\left.4 \mathrm{~h}\right)$ and acidified $(0.1 \mathrm{ml}$ $\mathrm{H}_{2} \mathrm{SO}_{4} 4 \mathrm{M}$ in $30 \mathrm{ml}$ of water). DOC was analyzed with a TOC analyzer (Aurora 1030 TOC Analyzer, O-I-Analytical). 


\subsubsection{Gas analyses}

\section{Dissolved carbon dioxide.}

Partial pressure of $\mathrm{CO}_{2}\left(\mathrm{pCO}_{2}\right)$ (ppmv) was measured in small SOs (1-3) and along the main stem (SOs 6-7), using a syringe headspace technique coupled with a non-dispersive infrared (NDIR) gas analyzer (Licor LI-820 or LI-840, USA) (Abril et al., 2015). In four syringes, 30 $\mathrm{ml}$ of stream water and $30 \mathrm{ml}$ of air were equilibrated in $\mathrm{CO}_{2}$ by shaking them continuously for 10 minutes. The first syringe was used to purge the system and measurements were made using the other three. Dry $\mathrm{pCO}_{2}$ was converted into $\mathrm{CO}_{2}$ water concentrations $\left(\mu \mathrm{gC} \mathrm{l}^{-1}\right)$ (Weiss, 1974; Weiss and Price, 1980).

We completed our data set of field measurements with existing datasets of $\mathrm{pH}$, total alkalinity and water temperature measurements from which we calculated $\mathrm{pCO}_{2}$ values (ppmv) with CO2SYS software algorithms (Pierrot et al., 2006) using water temperature, alkalinity and $\mathrm{pH}$ measurements for the period $2007-2017$ (22,142 of these three variables, i.e., around 1,400 stations distributed throughout the Seine Basin at a monthly to bimonthly frequency ) collected by the French water authorities - AESN). The carbonate dissociation constants (K1 and K2) applied were from (Millero, 1979) with zero salinity. $\mathrm{CO}_{2}$ solubility was from Weiss (1974). The $\mathrm{pCO}_{2}$ were corrected by the relationships established between direct and indirect $\mathrm{pCO}_{2}$ measurements for the Seine River basin (Marescaux et al., 2018; see Annex 1-2) to reduce $\mathrm{pCO}_{2}$ indirect calculation bias (see Abril et al., 2015b).

Annual means of atmospheric wet $\mathrm{pCO}_{2}$ values were provided by the NOAA/ESRL (http://www.esrl.noaa.gov/gmd/ccgg/trends/, Scripps Institution of Oceanography scrippsco2.ucsd.edu/, 2018/01/05) and averaged over the period 2007 -2017. Atmospheric wet $\mathrm{pCO}_{2}$ values were converted into dry values according to Weiss and Price (1980) using a relationship between the air and water temperatures for the Seine basin (Ducharne, 2008). Atmospheric wet $\mathrm{pCO}_{2}$ and $\mathrm{pCO}_{2}$ was used to calculate $\mathrm{CO}_{2}$ concentrations $\left(\mu \mathrm{gC}^{-1}\right)$ at equilibrium in the water with $\mathrm{CO}_{2}$ solubility (Weiss, 1974).

\section{Dissolved nitrous oxide (N2O) and methane (CH4).}

$\mathrm{N}_{2} \mathrm{O}$ concentrations were determined with a gas chromatograph (Perichrom ST 200) combined $^{2}$ with an electron capture detector (GC-ECD) (Garnier et al. 2007 and 2009). $\mathrm{CH}_{4}$ 
concentrations were also measured using a gas chromatograph coupled to a flame ionization detector (GC-FID) (Garnier et al., 2013). Only the three 2010 campaigns were already included in Garnier et al. (2013) for $\mathrm{CH}_{4}$. For $\mathrm{N}_{2} \mathrm{O}$ and $\mathrm{CH}_{4}$ determination, we used the same sampling and laboratory procedures as in the studies cited just above. 


\subsubsection{Calculation of indirect and direct emissions}

\section{Calculation of indirect emissions from hydrosystems}

The diffuse flux $\left(f(\mathrm{GHG}), \mathrm{mgC}-\mathrm{CO}_{2}, \mathrm{mgC}^{-} \mathrm{CH}_{4}\right.$ or $\mathrm{mgN}-\mathrm{N}_{2} \mathrm{O} \mathrm{m}{ }^{-2} \mathrm{day}^{-1}$ ) of $\mathrm{GHG}$ at the interface of the river and the atmosphere can be calculated as:

$$
f(G H G)=k_{G H G}\left([G H G]-[G H G]_{e q}\right)
$$

Eq. 1

where $[G H G]$ is the concentration of greenhouse gases in the water $\left(\mathrm{mgC}-\mathrm{CO}_{2} \mathrm{~m}^{-3}, \mathrm{mgC}-\mathrm{CH}_{4}\right.$ $\mathrm{m}^{-3}, \mathrm{mgN}^{-\mathrm{N}_{2} \mathrm{O} \mathrm{m}} \mathrm{m}^{-3}$ ), and $[G H G]_{e q}$ is the concentration of greenhouse gas at equilibrium with respect to atmospheric concentrations $\left(\mathrm{mgC}-\mathrm{CO}_{2} \mathrm{~m}^{-3}, \mathrm{mgC}^{-} \mathrm{CH}_{4} \mathrm{~m}^{-3}, \mathrm{mgN}-\mathrm{N}_{2} \mathrm{O} \mathrm{m}{ }^{-3}\right.$ ).

According to Wanninkhof (1992), Wilke and Chang (1955) and Raymond et al., (2012a), the gas transfer velocity $k_{G H G}\left(\mathrm{~m}\right.$ day $\left.^{-1}\right)$ under negligible wind conditions in rivers can be calculated as:

$$
k_{G H G}=k_{600} \cdot \sqrt{\frac{600}{S c_{G H G}(T)}}
$$

The $k_{600}$ (Eq. 3) in Raymond et al., (2012a) was selected as being appropriate to compare GHG emissions at large spatial scales, and for analyses of bulk biogeochemical budgets (Raymond et al., 2012a).

$$
k_{600}=v . S .2841 \pm a+2.02 \pm b
$$

where $v$ is the water velocity $\left(\mathrm{m} \mathrm{s}^{-1}\right)$ and $S$ the slope $(-) ; k_{600}$ is the gas transfer velocity for a Schmidt number of $600\left(\mathrm{~m} \mathrm{day}^{-1}\right)$. Coefficients $a$ and $b$ are standard deviations of 107 and 0.209 , respectively. The French water authority database - AESN, enabled estimation of the water velocity from water discharge records in the basin for the period 2012-2014, and also provided measured slopes. Slopes and water velocity were then averaged by SO and by season. 
Schmidt numbers $\left(S c_{G H G}(T)\right.$, dimensionless) of the calculated GHG (-) depend on water temperature $T$ in degree Celsius $\left({ }^{\circ} \mathrm{C}\right)$ as described in Wanninkhof (1992)

$S c_{\mathrm{CO}_{2}}(T)=1911.1-118.11 T+3.4527 T^{2}-0.041320 T^{3}$

$S c_{C H_{4}}(T)=1897.8+114.28 T+3.2902 T^{2}-0.039061 T^{3}$

$S c_{N_{2} O}(T)=2055.6-137.11 T+4.3173 T^{2}-0.054350 T^{3}$

Each flux was calculated for each SO and day. The total emission of the hydrosystem (E) $\left(\mathrm{mgC}-\mathrm{CO}_{2}\right.$ day $^{-1}, \mathrm{mgC}-\mathrm{CH}_{4}$ day $^{-1}$ or $\mathrm{mgN}-\mathrm{N}_{2} \mathrm{O}$ day $^{-1}$ ) corresponds (see Eq.7) to the sum of GHG fluxes calculated for each SO ( $\left.\mathrm{F}_{\mathrm{SO}}\right)$ multiplied by the number of rivers per $\mathrm{SO}\left(\mathrm{n}_{\mathrm{SO}}\right)$ and the average water surface of these SOs $\left(\mathrm{A}_{\mathrm{SO}}, \mathrm{m}^{2}\right)$. The number of rivers per $\mathrm{SO}\left(\mathrm{n}_{\mathrm{SO}}\right)$ and the water surface $\left(\mathrm{A}_{\mathrm{SO}}\right)$ were extracted from the drainage network based on the topological records of the French water authorities - AESN.

$$
E=\sum_{S O=1}^{8} \mathrm{~F}_{\mathrm{SO}} \mathrm{n}_{\mathrm{SO}} \mathrm{A}_{\mathrm{SO}}
$$

These values were averaged per period (summer-April to October- and winter-November to March-) and per SO (1-7). Finally, the annual estimate was assumed to have the combination of values calculated using average summer and winter characteristics (see Garnier et al., 2009 and 2013).

While humans have increased direct emissions through agricultural and industrial activities, emissions have also increased indirectly in aquatic and semi-aquatic (lake, river, riparian zone) and terrestrial (e.g., forest) ecosystems (Jurado et al., 2017).

\section{Direct greenhouse gas emissions from agricultural and nonagricultural activities in the}

\section{Seine basin}

We used the estimations of $\mathrm{N}_{2} \mathrm{O}$ and $\mathrm{CH}_{4}$ emissions caused by agricultural activities in the Seine basin reported in previous studies (Garnier et al., 2009 and 2013). 
$\mathrm{N}_{2} \mathrm{O}$ agricultural emissions were calculated from a review of emission coefficients for the major land use classes (croplands, grasslands and forests). An ongoing study aiming at refining $\mathrm{N}_{2} \mathrm{O}$ emissions by accounting for a relation between $\mathrm{N}_{2} \mathrm{O}$ emissions and mineral nitrogen fertilizers applied under different classes of rainfall would approximately amount 9 $\mathrm{GgN}-\mathrm{N}_{2} \mathrm{O} \mathrm{yr}^{-1}$ close to the $11.4 \mathrm{GgN}^{-N_{2}} \mathrm{O} \mathrm{yr}^{-1}$ previously reported in Garnier et al. (2009), established from a different approach, and used here.

The total amount of $\mathrm{CH}_{4}$ emitted from agricultural sources, i.e., essentially by livestock (enteric fermentation and manure degradation) was calculated based on the number of animals per species and per age in the Seine Basin, and the specific emission factors for each species $\left(\mathrm{kg}_{-} \mathrm{CH}_{4}\right.$ head $^{-1}$ year $\left.^{-1}\right)$ (Garnier et al., 2013). Again, according to Garnier et al. (2013), we estimated $\mathrm{CO}_{2}$ emissions from agricultural sources considering the use of $180 \mathrm{kgN} \mathrm{ha}^{-1} \mathrm{yr}^{-1}$ nitrogen fertilizers on agricultural land and the emission of $0.52 \mathrm{tC}-\mathrm{CO}_{2}$ per ton of $\mathrm{N}$ fertilizers produced. We also assumed that $1001 \mathrm{ha}^{-1} \mathrm{yr}^{-1}$ of fossil energy is required for farm work. Taking into account the cropped area, these emissions amounted to $622 \mathrm{Gg} \mathrm{C}-\mathrm{CO}_{2} \mathrm{yr}^{-1}$ (Garnier et al., 2013). As a first approximation, we disregarded the effect of possible sequestration by soils and emissions linked to changes in land use.

We estimated nonagricultural GHG emissions based on data in Wu et al. (2016) and Staufer et al., (2016) for the Ile-de-France Region, while data at the scale of the French administrative Departments were used for the rest of the Seine basin, excluding Ile-de-France (available at https://www.citepa.org/fr/, 2018/01/05, from_CITEPA, French Interprofessional Technical Center for Studies on Air Pollution, last accessed 2018/11/05). CITEPA provides accurate census data on urban GHG emissions including energy transformation, manufacturing, the service sector and transport using the CORe Inventory AIR emissions methodology (CORINAIR, https://www.eea.europa.eu/publications/EMEPCORINAIR, last accessed 2018/11/05) from the European Environment Agency with a NUTS 3 resolution (French Departments). To analyze the nonagricultural emissions separately, we grouped the different sectors in three major classes:

(i) energy transformation + manufacturing,

(ii) residential + tertiary sectors,

(iii) transport 
All nonagricultural GHG emissions were collected with spatially explicit references and processed using GIS technology (QGIS Development Team, 2016) to be scaled to the limits of the Seine River basin. Total GHG emissions were estimated by summing riverine, agricultural and nonagricultural GHG emissions.

\subsubsection{Statistical analyses}

The GHG concentrations and associated water temperatures were bootstrapped with 10,000 iterations, using the R package "boot.ci" (R Core team, 2015) in order to obtain mean, standard deviation and 95\% confident intervals for each season and each SO. This procedure allows estimating the distribution of a sample from a limited dataset. For each bootstrap, the consistency between the generated mean value and that of the original dataset was checked. The uncertainty of the GHG flux (expressed as 95\% confidence interval) was quantified with Monte Carlo simulations using equation (1) consisting of 10,000 runs (Beck, 1987). The required distributions of the input parameters were either provided by the bootstrapping (for GHG concentrations and water temperatures) or equation (3) for the gas exchange velocities assuming a Gaussian distribution of coefficient $a$ and $b$. For these calculations, we also assume that each of these parameters varies independently from one another.

The variability of GHG concentrations and gas transfer velocity between orders and seasons was tested using Kruskal-Wallis and Wilcoxon signed-rank tests, respectively. Coefficients of determination $\left(\mathrm{R}^{2}\right)$ were used to check for correlations between GHG concentrations, nutrients and environmental parameters. Significant correlations are designated by an asterisk, taking into account the number of data.

\subsection{Results}

\subsubsection{Greenhouse gas concentrations in the hydrological network}

The annual mean $\mathrm{CO}_{2}$ concentrations in the water were spatially significantly higher for the first and last SOs $\left(>2,000 \mu \mathrm{gC}-\mathrm{CO}_{2} 1^{-1}\right)$, similar to $\mathrm{N}_{2} \mathrm{O}\left(>1 \mu \mathrm{gN}-\mathrm{N}_{2} \mathrm{Ol}^{-1}\right)$. The annual mean $\mathrm{CH}_{4}$, concentrations were only significantly higher in the $7^{\text {th }} \mathrm{SO}$, especially in summer (> 3 $\mu \mathrm{gC}-\mathrm{CH}_{4} \mathrm{l}^{-1}$ ) (Fig. 2) (Annex 1-5). The mean annual concentrations in medium river SOs (35) were generally lower $\left(<2000 \mu \mathrm{gC}^{-1}\right.$ for $\mathrm{CO}_{2},<1.5 \mu \mathrm{gC} l^{-1}$ for $\mathrm{CH}_{4}$, and $\sim 0.6 \mu \mathrm{gN} \mathrm{l}^{-1}$ for 
$\mathrm{N}_{2} \mathrm{O}$ ). No significant differences in $\mathrm{N}_{2} \mathrm{O}$ concentrations were found in any of the SOs in the two seasons selected (winter and summer). $\mathrm{CO}_{2}$ concentrations were only significantly higher in summer than in winter in the $1^{\text {st }} \mathrm{SO}$ whereas summer $\mathrm{CH}_{4}$ concentrations were higher in the majority of SOs (Fig. 2, Table Annex 1-4).
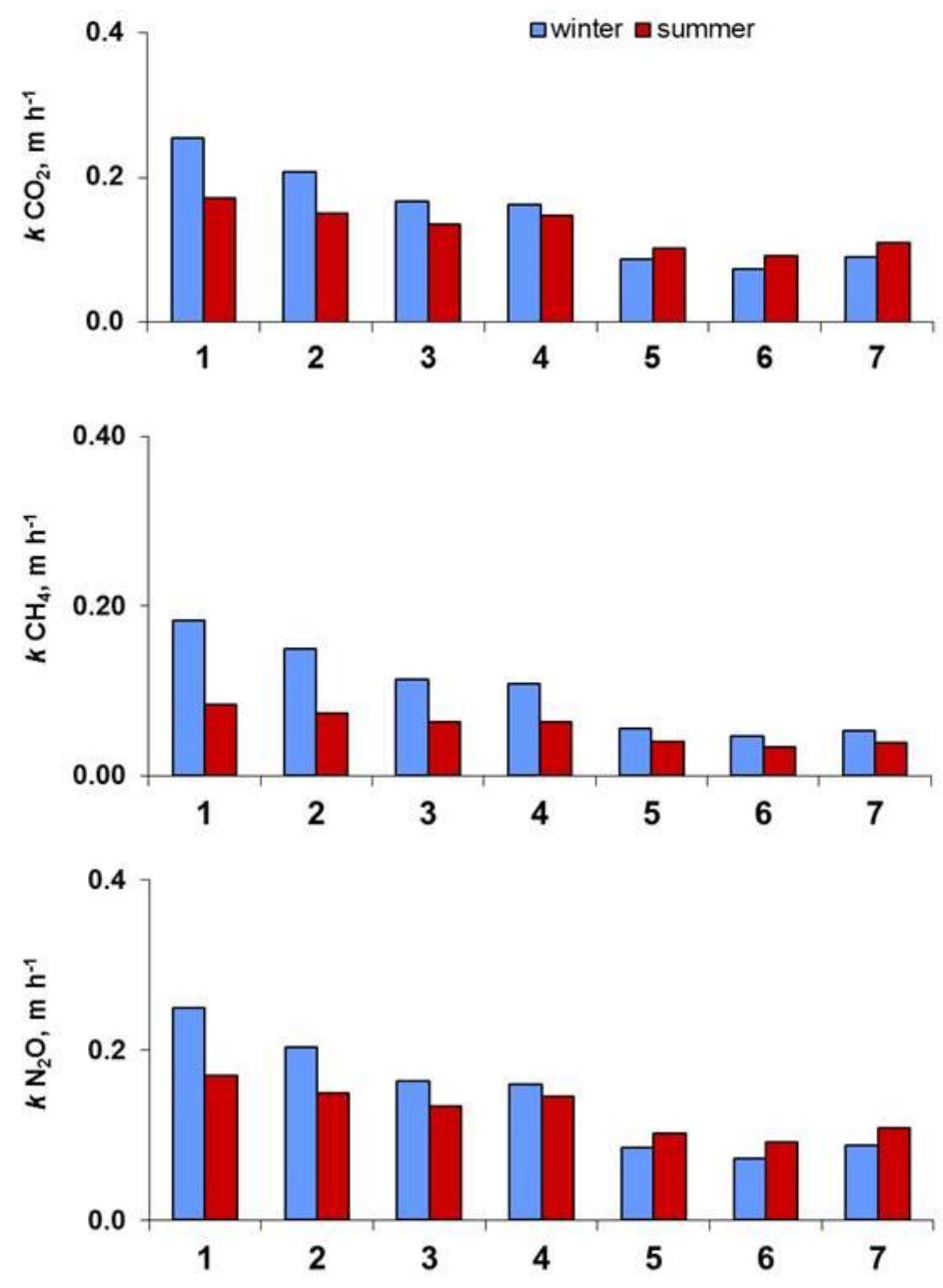

Fig. 2 Greenhouse gas $\left(\mathrm{CO}_{2}, \mathrm{CH}_{4}, \mathrm{~N}_{2} \mathrm{O}\right)$ concentrations in water $\left(\mu \mathrm{gC}-\mathrm{CO}_{2} \cdot \mathrm{l}^{-1}, \mu \mathrm{gC}-\mathrm{CH}_{4} \mathrm{l}^{-1}\right.$ and $\left.\mu \mathrm{gN}-\mathrm{N}_{2} \mathrm{O} \mathrm{l}^{-1}\right)$ as a function of the stream order in the Seine drainage network in winter and summer averaged from the 14 campaigns conducted between 2010 and 2017. Whiskers are standard deviations between observed GHG concentrations.

Atmospheric annual mean dry $\mathrm{pCO}_{2}$ concentrations were around $398 \pm 0.12 \mathrm{ppmv}$ on average for the 2010-2017 period (Division Physical Sciences and NOAA Earth System Research Laboratory), which gave an average concentration at equilibrium of $213 \mu \mathrm{gC}{ }^{-1}$ with a range of $151-331 \mu \mathrm{gC} 1^{-1}$ for all the campaigns. Aquatic $\mathrm{CO}_{2}$ concentrations in winter and in 
summer were always supersaturated with respect to atmospheric concentrations. Similarly, $\mathrm{N}_{2} \mathrm{O}$ and $\mathrm{CH}_{4}$ concentrations in the range of $\mu \mathrm{g}$, were systematically above the saturation level of the water (mean $\mathrm{N}_{2} \mathrm{O}$ saturation value: $275 \mathrm{ngN} \mathrm{l}^{-1}$ with a range of $115-490 \mathrm{ngN} \mathrm{1}^{-1}$; mean $\mathrm{CH}_{4}$ saturation value: $43 \mathrm{ngC}^{-1}$ with a range of 27-61 $\mathrm{ngC}^{-1}$ ).

Our data set enabled us to focus on the three GHG concentrations along the main streams of the Marne River (Fig. 3, from -365 to $0 \mathrm{~km}$, SO 6) and the lower Seine River (Fig. 3, km from 0 to $\pm 350 \mathrm{~km}, \mathrm{SO} 7$ ) where the concentrations were the highest (Fig. 3; see also Fig. 2).
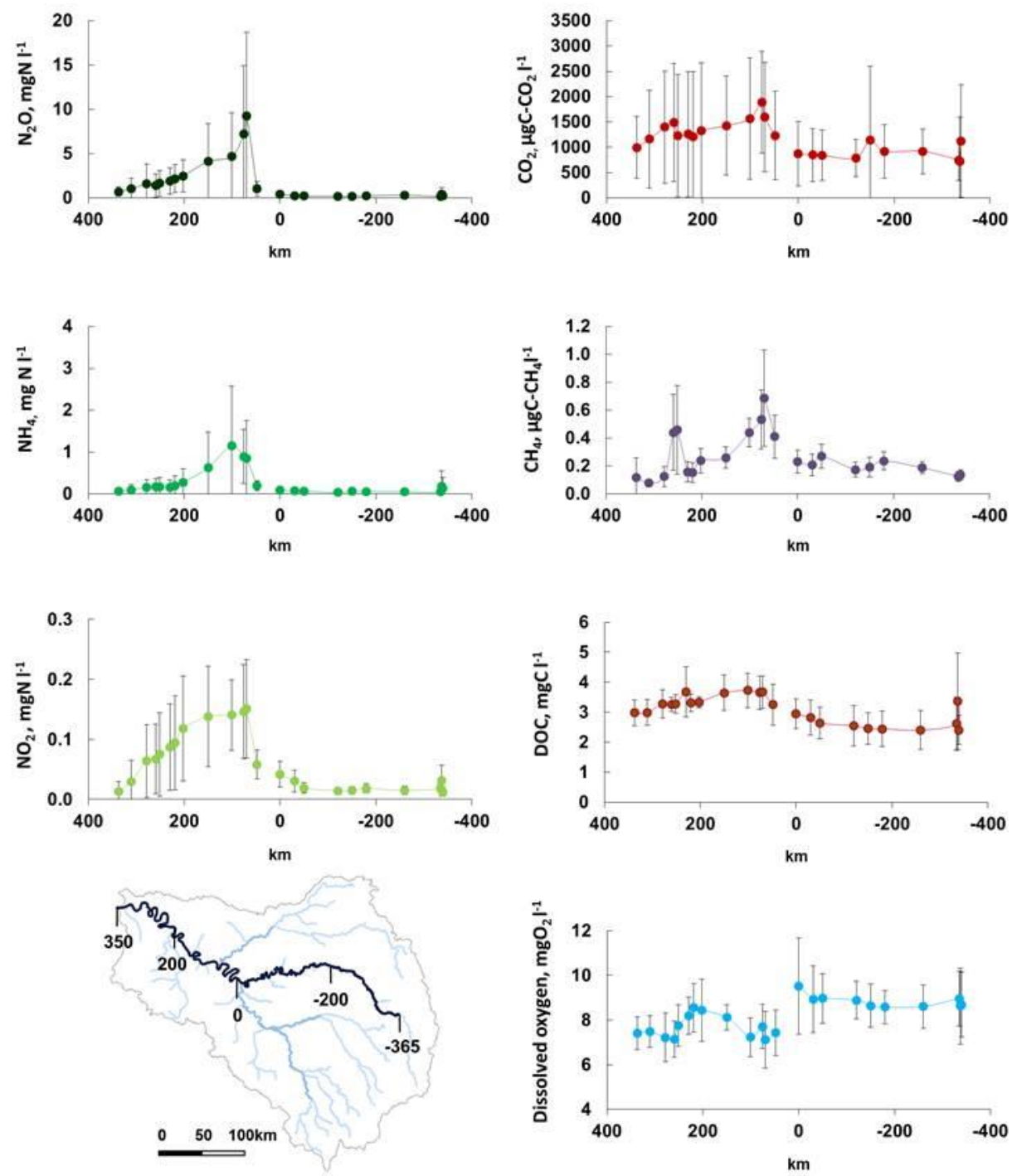

Fig. 3 Greenhouse gas $\left(\mathrm{CO}_{2}, \mathrm{CH}_{4}\right.$ and $\left.\mathrm{N}_{2} \mathrm{O}\right)$ and oxygen concentrations along the main stem of the Marne River

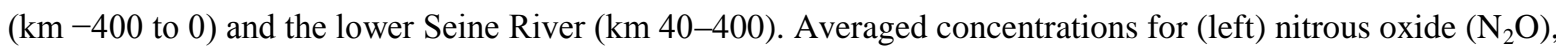
ammonium $\left(\mathrm{NH}_{4}{ }^{+}\right)$and nitrite $\left(\mathrm{NO}_{2}^{-}\right)$in $\mathrm{mgN} \mathrm{l}^{-1}$; (right) carbon dioxide $\left(\mathrm{CO}_{2}\right)$ and methane $\left(\mathrm{CH}_{4}\right)$ in $\mu \mathrm{gCl} \mathrm{l}^{-1}$, 
dissolved organic carbon (DOC) in $\mathrm{mgCl} \mathrm{l}^{-1}$, and dissolved oxygen in $\mathrm{mgO}_{2} \mathrm{1}^{-1}$. The $\mathrm{pCO}_{2}$ values were calculated from $\mathrm{pH}$, temperature and alkalinity using CO2SYS software (Pierrot et al., 2006). These data are partly described in Garnier et al. (2009 and 2013). 
The 11 longitudinal profile campaigns (from April to October i.e., in the summer period) were averaged for each GHG concentration for 2010-2014, and for each station (10 on the Marne branch and 13 on the lower Seine, Fig. 3). Despite wide variability, the longitudinal profiles of three $\mathrm{GHG}$ gases $\left(\mathrm{CO}_{2}, \mathrm{CH}_{4}, \mathrm{~N}_{2} \mathrm{O}\right)$ shared similar spatial trends of their concentrations (Fig. 3). Indeed, the concentrations were highest downstream from the effluent outlets in the Paris conurbation and from the city of Rouen. These patterns mirrored $\mathrm{NO}_{2}{ }^{-}, \mathrm{NH}_{4}{ }^{+}$and DOC concentrations that are typically high in wastewater effluents. As nitrification and organic matter degradation consume oxygen, the opposite trend was observed for oxygen concentrations (Fig. 3).
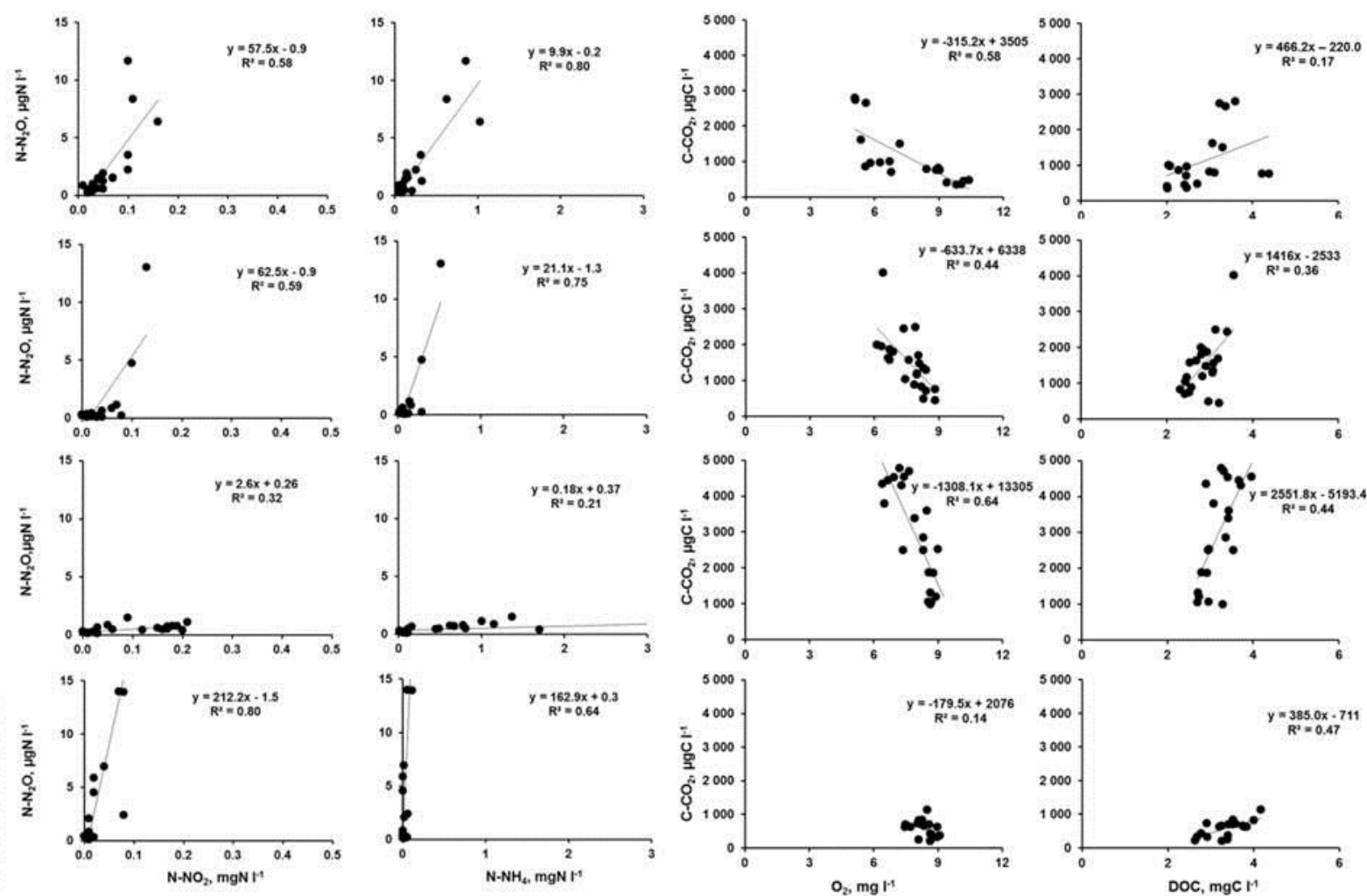

Fig. 4 Relationships between (a) concentrations of $\mathrm{N}_{2} \mathrm{O}\left(\mu \mathrm{gN} \mathrm{l}{ }^{-1}\right)$ and $\mathrm{NO}_{2}^{-}\left(\mathrm{mgN} \mathrm{l}^{-1}\right)$, (b) concentrations of $\mathrm{N}_{2} \mathrm{O}$ $\left(\mu \mathrm{gN} \mathrm{l}^{-1}\right)$ and $\mathrm{NH}_{4}{ }^{+}\left(\mathrm{mgN}^{-1}\right)$, (c) $\mathrm{CO}_{2}\left(\mu \mathrm{gCl}^{-1}\right)$ and oxygen $\left(\mathrm{mgO}_{2} \mathrm{l}^{-1}\right)$, and (d) $\mathrm{CO}_{2}\left(\mu \mathrm{gCl}^{-1}\right)$ and dissolved organic carbon (DOC: $\mathrm{mgC}^{-1}$ ). From top to bottom, example from the campaigns in May 2010, September 2012, September 2013 and September 2014. 
Of these 11 campaigns, eight showed a positive significant relationship $\left(\mathrm{R}^{2}>0.55 ; n=23\right)$ between $\mathrm{N}_{2} \mathrm{O}$ and $\mathrm{NO}_{2}{ }^{-}$concentrations, and in six, $\mathrm{N}_{2} \mathrm{O}$ was also correlated with $\mathrm{NH}_{4}^{+}\left(\mathrm{R}^{2}>\right.$ $0.40 ; n=23$ ) (Fig. 4, Table 1-1).

No relationship was found between $\mathrm{N}_{2} \mathrm{O}$ and $\mathrm{NO}_{3}{ }^{-} \cdot \mathrm{CO}_{2}$ was positively and significantly correlated with DOC ( ix out of 11 campaigns, $\mathrm{R}^{2}>0.27 ; n=23$ ) and negatively correlated with oxygen (five out of 11 campaigns, $\mathrm{R}^{2}>0.35$ ), but no correlation was found between $\mathrm{CH}_{4}$ concentrations and other variables of interest (e.g., $\mathrm{O}_{2}$, dissolved organic carbon). The slopes of the relationships varied greatly (by a factor of 100), depending on the discharge and the temperature during the campaigns (Fig. 4; Table 1-1).

Table 1-1 Parameters of the linear relationships (slope and $\mathrm{R}^{2}$ ) of $\mathrm{N}_{2} \mathrm{O}$ as a function of nitrite $\left(\mathrm{NO}_{2}^{-}\right)$and ammonium $\left(\mathrm{NH}_{4}^{+}\right)$, and of $\mathrm{CO}_{2}$ as a function of oxygen $\left(\mathrm{O}_{2}\right)$ and dissolved organic carbon (DOC) for each of the 11 campaigns. Corresponding values of mean discharges and temperatures (temp) for the duration of the campaign are indicated. *Slope significantly different from 0 for $\mathrm{R}^{2}>0.16(n>20)$.

\begin{tabular}{|c|c|c|c|c|c|c|c|c|c|c|}
\hline Dates & $\begin{array}{c}\text { Discharge } \\
\mathrm{m}^{3} \mathrm{~s}^{-1}\end{array}$ & $\begin{array}{c}\text { temp } \\
{ }^{\circ} \mathrm{C}\end{array}$ & $\begin{array}{l}\mathrm{N}_{2} \mathrm{O} \text { vs. } \mathrm{NO}_{2} \\
\mu \mathrm{gN} \mathrm{^{-1 }} \mathrm{mgN} \mathrm{l}^{-1}\end{array}$ & $\mathrm{R}^{2}$ & $\begin{array}{c}\mathrm{N}_{2} \mathrm{O} \text { vs. } \mathrm{NH}_{4} \\
\mu \mathrm{gN} \mathrm{l}^{-1} \mathrm{mgN} \mathrm{I}^{-1}\end{array}$ & $\mathrm{R}^{2}$ & $\begin{array}{c}\mathrm{CO}_{2} \text { vs. } \mathrm{O}_{2} \\
\mu \mathrm{gC} \mathrm{\textrm {I } ^ { - 1 }} \mathrm{mgC}^{-1}\end{array}$ & $\mathrm{R}^{2}$ & $\begin{array}{l}\mathrm{CO}_{2} \text { vs. DOC } \\
\mu \mathrm{gC} \mathrm{l}^{-1} \mathrm{mgC}^{-1}\end{array}$ & $\mathrm{R}^{2}$ \\
\hline 3-5 May 2010 & 282.3 & 14.8 & 57.5 & $0.58^{*}$ & 9.9 & $0.80^{*}$ & -315.2 & $0.58^{\star}$ & 466.2 & $0.17^{\star}$ \\
\hline 5-7 July 2010 & 161.0 & 16.1 & 39.8 & $0.78^{*}$ & 12.7 & $0.61^{*}$ & -30.2 & 0.01 & 183.9 & 0.06 \\
\hline 2, 4-7 October 2010 & 347.3 & 16.1 & 85.3 & $0.73^{*}$ & 21.7 & $0.81^{*}$ & -290.4 & 0.14 & 398.0 & $0.36^{\star}$ \\
\hline 17-19 May 2011 & 184.3 & 18.4 & 1.4 & $0.29^{*}$ & 0.1 & $0.17^{*}$ & -143.6 & $0.36^{*}$ & 307.0 & $0.27^{\star}$ \\
\hline 23-25, 27-28 August 2011 & 229.7 & 22.0 & 15.5 & $0.57^{*}$ & 2.5 & $0.17^{*}$ & -34.8 & 0.12 & 57.2 & 0.12 \\
\hline 4-10 April 2012 & 289.0 & 12.8 & 33.5 & $0.77^{*}$ & 7.9 & $0.42^{*}$ & -60.7 & NA & 177.4 & 0.01 \\
\hline 29 Sept-3 August 2012 & 169.3 & 21.0 & 62.5 & $0.59^{*}$ & 21.1 & $0.75^{\star}$ & -633.7 & $0.44^{*}$ & 1416.0 & $0.36^{*}$ \\
\hline 17-20, 22-23 June 2013 & 659.7 & 18.8 & 18.1 & $0.67^{*}$ & 3.7 & $0.25^{*}$ & -306.7 & $0.23^{*}$ & 275.2 & $0.21^{\star}$ \\
\hline $16,18-19,21-22$ Sept. 2013 & 353.6 & 16.9 & 2.6 & $0.32^{*}$ & 0.2 & $0.21^{*}$ & -1308.1 & $0.64^{*}$ & 2551.8 & $0.44^{\star}$ \\
\hline 13-17 May 2014 & 327.6 & 15.3 & 8.1 & $0.28^{*}$ & 0.7 & 0.12 & -554.5 & $0.37^{*}$ & 526.6 & $0.65^{\star}$ \\
\hline 9-11 Sept 2014 & 252.0 & 19.6 & 212.2 & $0.80^{*}$ & 162.9 & $0.64^{*}$ & -179.5 & 0.14 & 385.0 & $0.47^{\star}$ \\
\hline
\end{tabular}

\subsubsection{Greenhouse gas emissions from the hydrological network}

The difference in GHG concentrations between the atmosphere and the surfaces of the water, and gas transfer velocities, control emissions of GHGs. Gas transfer velocity depended on $k_{600}$ (Eq. 3) and on the Schmidt number (Eq. 4-6). $k_{600}$ decreased with SOs due to the decreasing slope, and increased with water velocity as a result of turbulence. Schmidt numbers depend on 
temperature sensitivities of the specific solubility of the different gases, resulting in different $k$ patterns (Annex 1-3).

Greenhouse gas emission fluxes showed that the Seine hydrological network is a source of three gases $\left(\mathrm{CO}_{2}, \mathrm{CH}_{4}\right.$ and $\left.\mathrm{N}_{2} \mathrm{O}\right)$ to the atmosphere. In particular, budgets showed that $\mathrm{CO}_{2}$ summer emissions $\left(1,44010^{3} \mathrm{kgC}-\mathrm{CO}_{2}\right.$ day $\left.^{-1}\right)$ were lower than winter emissions $\left(1,80010^{3}\right.$ $\mathrm{kgC}-\mathrm{CO}_{2}$ day $^{-1}$ ) (annual amount $592 \mathrm{GgC}-\mathrm{CO}_{2} \mathrm{yr}^{-1}$ on average, Fig. 7). Seasonal $\mathrm{CH}_{4}$ emissions were $554 \mathrm{kgC}-\mathrm{CH}_{4}$ day $^{-1}$ and $433 \mathrm{kgC}^{-\mathrm{CH}_{4}}$ day $^{-1}$ in summer and winter, respectively (i.e., an average annual diffusive emission of $\left.0.180 \mathrm{GgC}^{-\mathrm{CH}_{4}} \mathrm{yr}^{-1}\right) . \mathrm{N}_{2} \mathrm{O}$ emissions amounted to $708{\mathrm{kgN}-\mathrm{N}_{2} \mathrm{O} \text { day }}^{-1}$ in summer and $601{\mathrm{kgN}-\mathrm{N}_{2} \mathrm{O} \text { day }}^{-1}$ in winter (i.e.,

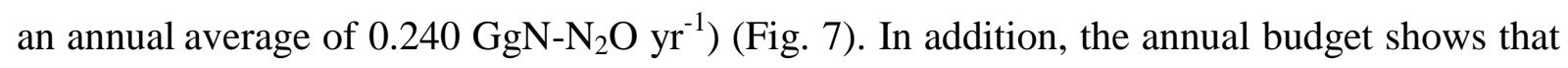
$44 \%$ of the $\mathrm{CO}_{2}$ emissions were emitted from the first and second SOs of the Seine basin, while the $6^{\text {th }}$ and $7^{\text {th }}$ SOs contributed the most nitrous oxide, more than $50 \%$ of the emissions. $\mathrm{CH}_{4}$ emissions were more evenly distributed among upstream (SOs 1, 2), intermediate (SOs $3,4,5)$ and downstream reaches (SOs 6, 7).

Considering global warming potential (GWP) for the last 100 years, i.e. 28 for $\mathrm{CH}_{4}$ and 265 for $\mathrm{N}_{2} \mathrm{O}$, the hydrosystem's annual $\mathrm{N}_{2} \mathrm{O}$ budget $\left(99 \mathrm{Gg} \mathrm{CO}_{2} \mathrm{eq} \mathrm{yr}^{-1}\right.$ ) was 14 times higher than $\mathrm{CH}_{4}$ diffusive emissions ( $7 \mathrm{Gg} \mathrm{CO}_{2} \mathrm{eq} \mathrm{yr}^{-1}$ ), an $\mathrm{N}_{2} \mathrm{O}$ budget that itself was around 22 times lower than the $\mathrm{CO}_{2}$ budget $\left(2,170 \mathrm{Gg} \mathrm{CO}_{2} \mathrm{eq} \mathrm{yr}{ }^{-1}\right)$ (Fig. 7, Table 1-2).

Table 1-2 Comparative greenhouse gas $\left(\mathrm{Gg} \mathrm{CO}_{2}\right.$ eq yr ${ }^{-1}$ of $\mathrm{CO}_{2}, \mathrm{CH}_{4}$ and $\left.\mathrm{N}_{2} \mathrm{O}\right)$ emissions from the hydrographic network (measurements made in this study), from the agricultural basin (including croplands, grasslands and forests according to Garnier et al. (2009 and 2013) and from nonagricultural sectors (data from CITEPA 2005 and from Wu et al. (2016) for the Ile-de-France region). $\sum$ GHG: sum of the three GHGs by compartment and by gas.

\begin{tabular}{|c|c|c|c|c|}
\hline & Hydrosystem & $\begin{array}{l}\text { Agri. areas } \\
10^{6} \mathrm{~kg} \mathrm{CO}_{2} \mathrm{eq}\end{array}$ & Nonagri. & $\begin{array}{c}\sum \mathrm{GHG} \\
10^{6} \mathrm{~kg} \mathrm{CO}_{2} \mathrm{eq} \mathrm{yr} \mathrm{yr}^{-1}\end{array}$ \\
\hline $\mathrm{CO}_{2}$ & 678 & 2,281 & 44,077 & 47,036 \\
\hline $\mathrm{CH}_{4}$ & 14 & 7,267 & 360 & 7,642 \\
\hline $\mathrm{N}_{2} \mathrm{O}$ & 99 & 4,747 & 276 & 5,122 \\
\hline$\sum \mathrm{GHG}$ & 791 & 14,295 & 44,714 & 59,800 \\
\hline
\end{tabular}


Interestingly, $\mathrm{CO}_{2}$ emissions accounted for $95.3 \%$ of the three $\mathrm{GHG}$ emissions from the hydrosystem (indirect emissions), while $\mathrm{N}_{2} \mathrm{O}$ and $\mathrm{CH}_{4}$ emissions accounted for $4.4 \%$ and $0.3 \%$, respectively.

\subsubsection{Emissions from agricultural and nonagricultural sectors}

Total GHG emissions from the agricultural basin were estimated at $14,295 \mathrm{Gg} \mathrm{CO}_{2} \mathrm{eq}^{-1}$. $\mathrm{CH}_{4}, \mathrm{~N}_{2} \mathrm{O}$ and $\mathrm{CO}_{2}$ emissions contributed $51 \%, 33 \%$ and $16 \%$ of agricultural emissions, respectively (Table 1-2).

Total direct GHG emissions from the nonagricultural basin were estimated at $44,713 \mathrm{Gg}$ $\mathrm{CO}_{2}$ eq $\mathrm{yr}^{-1}$, the majority from the Ile-de-France region (92\%). Nonagricultural emissions of $\mathrm{CO}_{2}$ were more than 100 times higher than those of $\mathrm{CH}_{4}$ and $\mathrm{N}_{2} \mathrm{O}$ (Table 1-2). Whereas $\mathrm{CO}_{2}$ emissions were rather well distributed among the categories, $\mathrm{CH}_{4}$ and $\mathrm{N}_{2} \mathrm{O}$ emissions occurred mainly in the energy \& manufacturing sector. These emissions were approximately three times higher than the sum of those from the residential \& tertiary and transport sectors (Fig. 5).

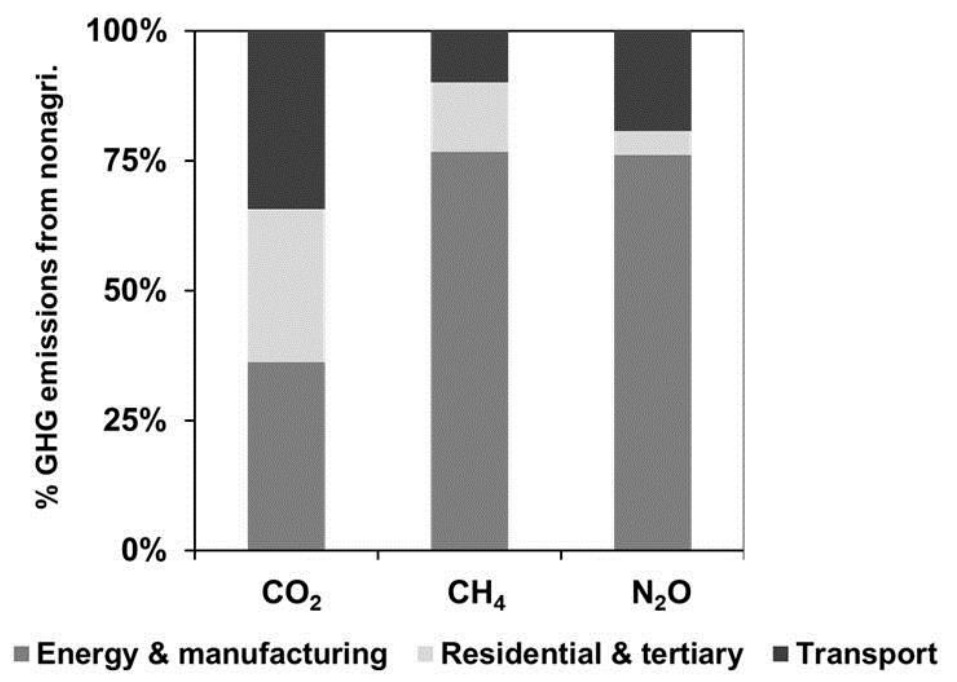

Fig. 5 Greenhouse gas emissions $\left(\mathrm{CO}_{2}, \mathrm{CH}_{4}\right.$ and $\left.\mathrm{N}_{2} \mathrm{O}\right)$ from nonagricultural sectors $\left(\mathrm{Gg} \mathrm{CO}_{2}\right.$ eq yr $\left.{ }^{-1}\right)$ in the Seine watershed including energy transformation-manufacturing, service sector, and transport (GIS treatments applied to CITEPA data; https://www.citepa.org/fr/, 2018/01/05) 


\subsubsection{Total GHG emissions from the Seine basin}

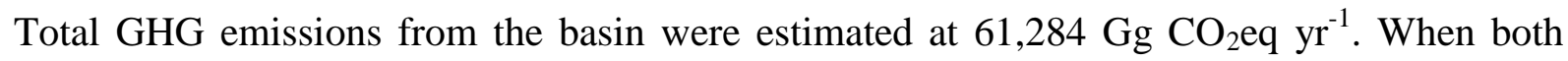
direct emissions (including agricultural and nonagricultural activities) and indirect emissions (from the hydrosystem) were summed, the value was much higher for $\mathrm{CO}_{2}\left(48,528 \mathrm{Gg} \mathrm{CO}_{2} \mathrm{eq}\right.$ $\mathrm{yr}^{-1}$ ), while $\mathrm{CH}_{4}$ and $\mathrm{N}_{2} \mathrm{O}$ were estimated at 7,634 Gg CO2eq $\mathrm{yr}^{-1}$ and 5,122 $\mathrm{Gg} \mathrm{CO}_{2} \mathrm{eq} \mathrm{yr}^{-1}$, respectively (Fig. 6). While agricultural activities were responsible for a quarter of the total GHG emissions in the Seine basin (14,295 vs. 61,284 $\mathrm{Gg} \mathrm{CO}_{2} \mathrm{eq} \mathrm{yr}^{-1}$, Table 1-2), the hydrosystem only accounted for a small proportion of the total emissions of each of the three gases $4.5 \%$ for $\mathrm{CO}_{2}, 0.1 \%$ for $\mathrm{CH}_{4}$, and $1.9 \%$ for $\mathrm{N}_{2} \mathrm{O}$ (Fig. 6, Table 1-2).

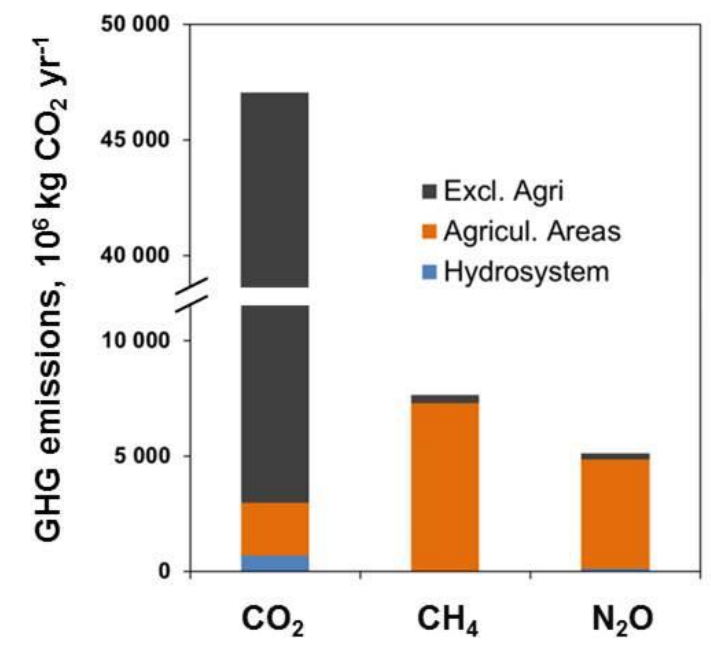

Fig. 6 Greenhouse gas emissions $\left(\mathrm{CO}_{2}, \mathrm{CH}_{4}\right.$ and $\mathrm{N}_{2} \mathrm{O}$ in $\left.\mathrm{Gg} \mathrm{CO}_{2} \mathrm{eq} \mathrm{yr}^{-1}\right)$ from the Seine hydrographic network and those from the watershed, divided into agricultural and nonagricultural (GIS treatments applied to CITEPA data; https://www.citepa.org/fr/, last accessed 2018/11/05); Data for Ile-de-France are from Wu et al. (2016) and Staufer et al. (2016).

\subsection{Discussion}

\subsubsection{Limits to our calculations of the emission}

To calculate gas emissions from the drainage network, $k$ was computed according to Raymond et al. (2012), which validated the equation on small streams. The equation selected for $k$ is linearly dependent on the slope and the water velocity averaged per SO and per season. Although the Seine catchment is relatively flat as the Seine source is located around 
$500 \mathrm{~m}$ asl. (French water authorities - AESN), the importance of the slope in $k$ can lead to under- or overestimation of GHG fluxes. Similarly, exceptional flood events resulting in high turbulence (and water velocity) were not taken into account in this study, which could bias our estimations. However, comparing our results with those previously published for $\mathrm{N}_{2} \mathrm{O}$ and $\mathrm{CH}_{4}$ using a different equation (Garnier et al., 2009 and 2013), did not change the numbers much. We thus consider that our results provide robust estimates, although there is a need for $k$ measurements in the Seine hydrosystem, which could increase the accuracy of GHG emissions. Although uncertainties persist in the estimates of GHG direct emissions in the Ilede-France region and the rest of the basin, we believe that the order of magnitude is also correct.

\subsubsection{Patterns of indirect $\mathrm{CO}_{2}, \mathrm{CH}_{4}, \mathrm{~N}_{2} \mathrm{O}$ emissions from rivers in the drainage network: differences and similarities}

Surprisingly, $95.3 \%$ of the indirect GHG emissions of the Seine drainage network were mainly linked to $\mathrm{CO}_{2}$, compared to $\mathrm{CH}_{4}(0.3 \%)$ and $\mathrm{N}_{2} \mathrm{O}(4.4 \%)$ emissions. Considering the higher stream orders (SOs) of the Seine River as productive systems (Garnier et al., 2005, 2007) and despite the recent decrease in algal bloom (Aissa-Grouz et al., 2016), we had expected uptakes of $\mathrm{CO}_{2}$ in the river network. Studying $\mathrm{pCO}_{2}$ at the scale of the whole Seine drainage network revealed oversaturation in $\mathrm{CO}_{2}$ at all locations and in both seasons, which we interpreted as being caused by soil leaching as well as inputs from aquifers where concentrations were up to ten times higher than those in the surface water $(20,000-60,000$ ppm in the Brie aquifer, data not shown), and releases of effluents from WWTPs.

Oversaturation of the GHGs with respect to atmospheric concentrations was not only observed in the Seine River (see also Garnier et al., 2009 and 2013), but also in the other temperate river, the Meuse (Borges et al., 2018), where groundwater has also been reported to be a source of $\mathrm{CO}_{2}$ oversaturation. Contributions from groundwaters, quickly degassed at the head of the basin, were experimentally demonstrated by Garnier et al. (2009) for $\mathrm{N}_{2} \mathrm{O}$. Further, the higher GHG emissions in small SOs can be linked not only with higher concentrations but also with higher gas exchange rates ( $k$ and $k_{600}$ ) (see Eq. 2, 3), $k$ being linked with the slope of the basin, on average higher for lower SOs. 
In headwaters, allochthonous organic matter inputs and nitrate fertilizer leaching are also possible sources of GHG emissions from mineralization of organic carbon in the soil and groundwaters, along with denitrification in riparian zones (see Fig. 8; and Richey et al., 2002; Venkiteswaran et al., 2014). Denitrification in soils or sediments (i.e., nitrate reduction) is known to produce more $\mathrm{N}_{2} \mathrm{O}$ in anoxic or suboxic conditions (Garnier et al., 2010; Vilain et al., 2014; Benoit et al., 2015) than nitrification. Regarding $\mathrm{CH}_{4}$, anoxic organic-enriched locations of the river banks or in-stream sediment may enhance methanogenesis. While high $\mathrm{CO}_{2}$ and $\mathrm{CH}_{4}$ concentrations have been reported to be related to the extent and connectivity with wetlands in a tropical river system (Borges et al., 2015a; Teodoru et al., 2015), the (intensively cropped) Seine River basin only contains a small proportion of wetlands. We identified $\mathrm{CO}_{2}$ emissions from headwaters ( $1^{\text {st }}$ and $\left.2^{\text {nd }} \mathrm{SOs}\right)$ dominating the GHG source of the hydrosystem at 44\%, like Marx et al. (2017), who estimated that $36 \%$ of $\mathrm{CO}_{2}$ global riverine emissions originate from headwaters. In comparison to $\mathrm{CO}_{2}$ emissions for the Seine basin, $\mathrm{N}_{2} \mathrm{O}$ emissions from headwaters represented $34 \%$ and $\mathrm{CH}_{4}$ emissions only $25 \%$ of their respective total emissions (see Fig. 7). However in three US headwater streams draining land under mixed uses, Schade et al. (2016) found lower $\mathrm{CO}_{2}$ emissions in these mainly sandy streambeds, than in the carbonated streambeds in the Seine River, but potentially high $\mathrm{CH}_{4}$ and $\mathrm{N}_{2} \mathrm{O}$ emissions, probably due to organic-enriched streams where these authors reported a close relationship between total GHG emissions and concentrations of dissolved organic carbon (DOC).

In medium sectors of the Seine River, the decreasing contribution of groundwater as well as a decreasing ratio of terrestrial and riparian surface areas compared to the water volume could explain the lower emissions (Fig. 8). 


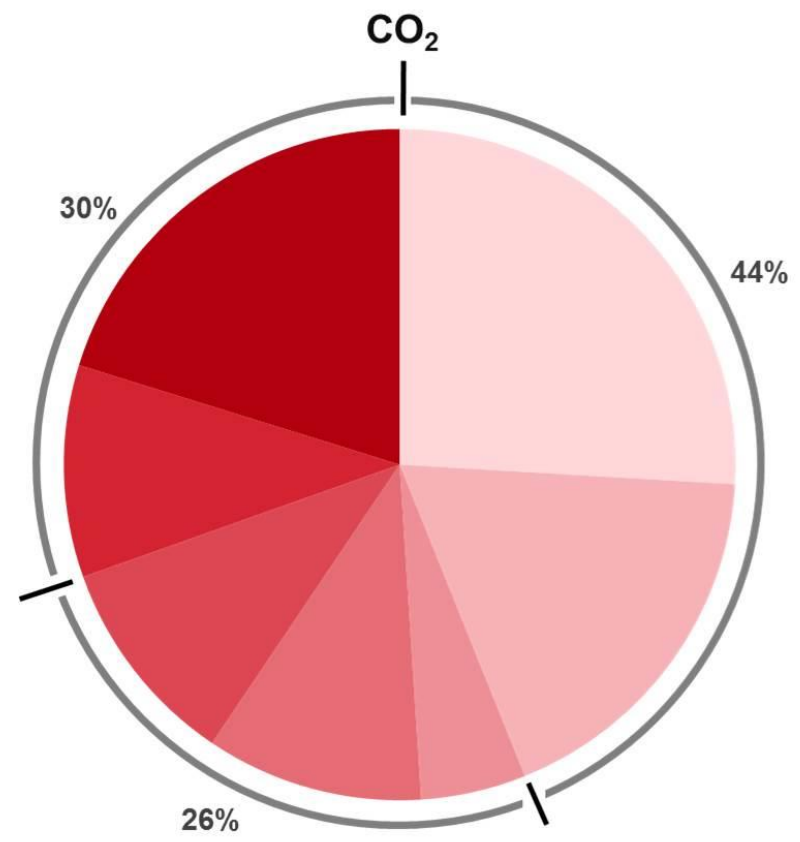

$67810^{6} \mathrm{~kg} \mathrm{CO}_{2} \mathrm{eq} \mathrm{yr}^{-1}$ $\left(18500010^{3} \mathrm{kgC}-\mathrm{CO}_{2} \cdot \mathrm{yr}^{-1}\right)$

\section{Strahler orders}
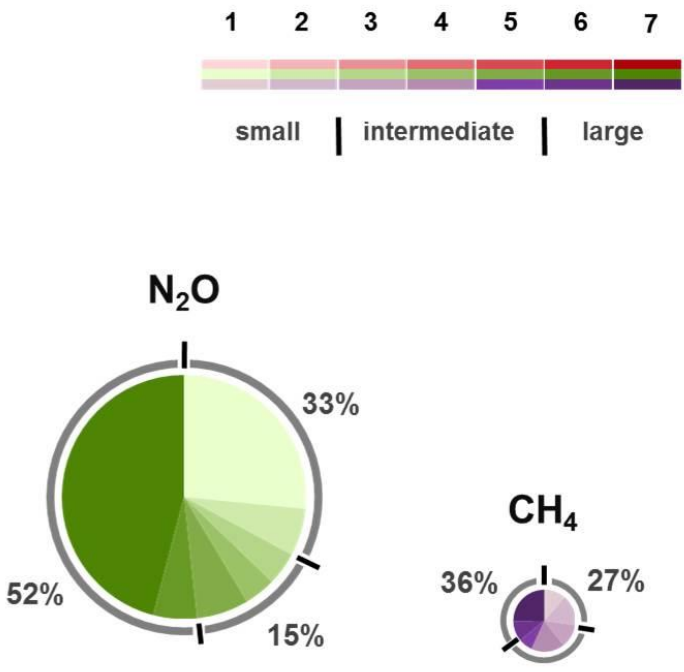

$37 \%$

$9910^{6} \mathrm{~kg} \mathrm{CO}_{2} \mathrm{eq} \mathrm{yr}^{-1} 1410^{6} \mathrm{~kg} \mathrm{CO}_{2} \mathrm{eq} \mathrm{yr}^{-1}$

$\left(24010^{3} \mathrm{kgN}-\mathrm{N}_{2} \mathrm{O} \mathrm{yr}^{-1}\right)$

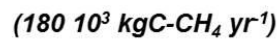

Fig. 7 Greenhouse gas $\left(\mathrm{CO}_{2}, \mathrm{CH}_{4}\right.$ and $\left.\mathrm{N}_{2} \mathrm{O}\right)$ emissions from the Seine hydrographic network (yearly average of 14 campaigns (2010-2017). The pie charts represent the proportion of GHG emissions expressed in GWP. Percentage contributions are given for small $\left(1^{\text {st }}\right.$ to $\left.2^{\text {nd }} \mathrm{SO}\right)$, intermediate $\left(3^{\text {rd }}\right.$ to $\left.5^{\text {th }} \mathrm{SO}\right)$ and large $\left(6^{\text {th }}\right.$ to $\left.7^{\text {th }} \mathrm{SO}\right)$ rivers in the Seine watershed. 
Higher emissions of the three GHGs in the higher SOs (6-7) can be interpreted as a response to WWTP effluents discharged downstream from the Paris conurbation (Fig. 8). As the water column was not fully anoxic even in the sector of effluent outlet, $\mathrm{CH}_{4}$ may be linked to methanogenesis in the sediment that is rich in settled organic matter, while $\mathrm{CO}_{2}$ is expected to result from organic matter respiration in both the water column and sediment (Battin et al. 2009; Vilmin et al. 2015; Garnier et al., 2009 and 2013). For $\mathrm{N}_{2} \mathrm{O}$ emissions, in addition to denitrification in suboxic zones (at the scale of the bottom sediment-water interface, but also at the particle level (Garnier et al., 2007, 2009; Jia et al., 2016; Xia et al., 2017), nitrification of the ammonium massively supplied by effluents was also a source of $\mathrm{N}_{2} \mathrm{O}$ emissions (Garnier et al., 2007, 2009; Burgos et al., 2017). With lower gaseous exchange rates calculated in these higher SOs, the emissions of the three GHGs accounted for $26 \%, 52 \%$ and $38 \%$ of the total drainage network flux for $\mathrm{CO}_{2}, \mathrm{CH}_{4}$ and $\mathrm{N}_{2} \mathrm{O}$, respectively in the $6^{\text {th }}$ and $7^{\text {th }}$ SOs (see Fig. 7).

\section{Seine River system}

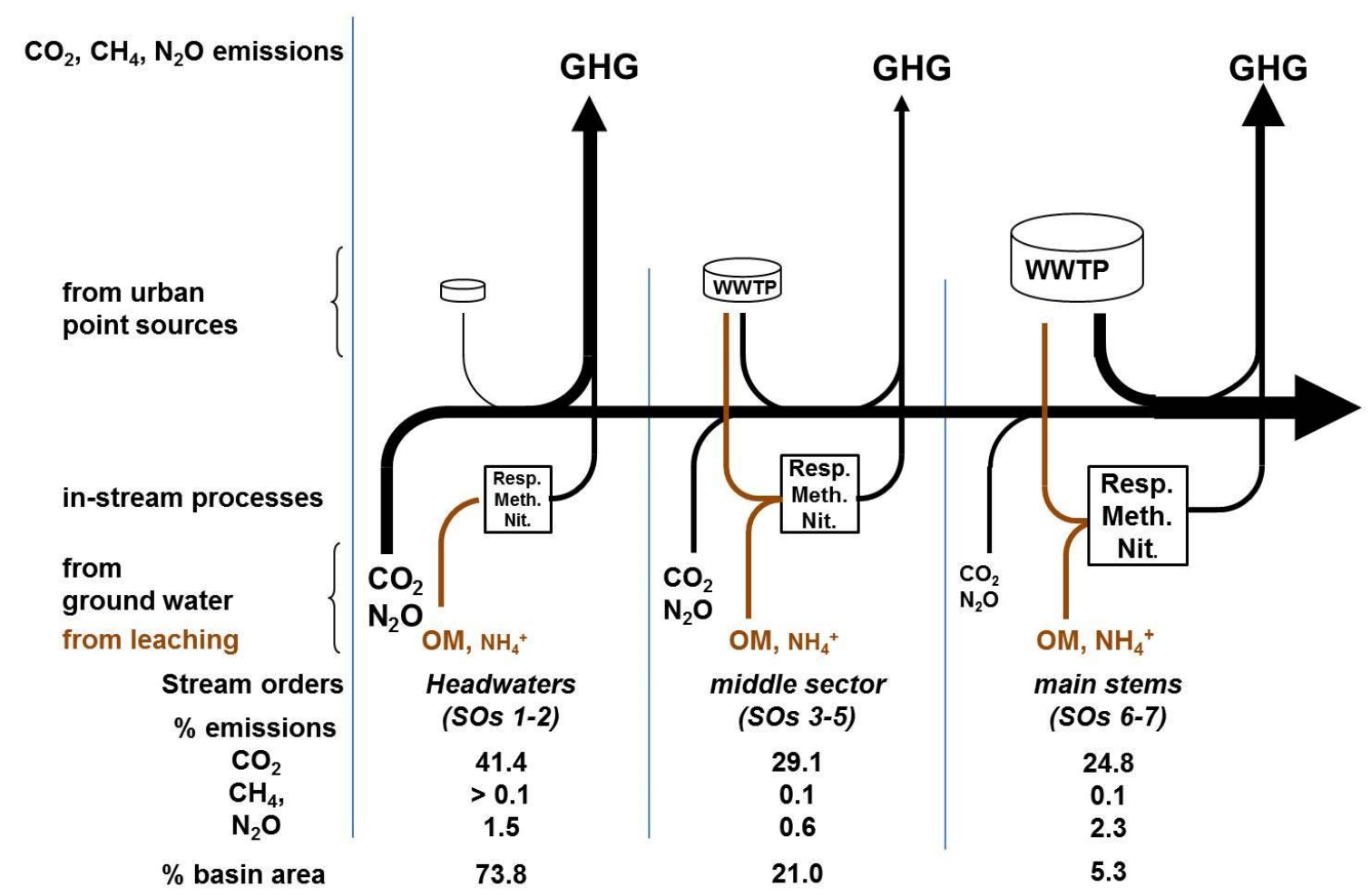

Fig. 8 Schematic representation of the sources of $\mathrm{CO}_{2}, \mathrm{CH}_{4}$ and $\mathrm{N}_{2} \mathrm{O}$ emissions from the Seine hydrosystem. OM: organic matter; $\mathrm{NH}_{4}^{+}$: ammonium 
Physiological processes enhanced by higher temperature did not systematically lead to higher GHG emissions in the summer, pointing to complex interactions between in-stream microbial processes (mineralization) and the contribution of groundwater (diffuse sources) and discharge of effluents (point sources). Upstream-downstream patterns of the three GHG concentrations, which were further detailed in 11 longitudinal profiles along the main stem of the Marne River and the lower Seine stem, showed "background" concentrations along the main stem of the Marne compared to the peaks observed downstream. The impact of the Parisian WWTPs was quite clear immediately downstream from their outlets and decreased within the $30 \mathrm{~km}$ downstream, partly due to dilution by the Oise River and in-stream processes. Farther downstream, GHG concentrations again increased, reflecting the major impact of the treated effluent from the Rouen conurbation. Although the number of inhabitant equivalents treated is 12 times higher in the Paris WWTPs than in Rouen's, the carbon load was only six times higher (i.e., a lower carbon abatement in the Rouen WWTP, with its smaller capacity), explaining the high impact. Such an impact of point source pollution, i.e., a discharge of labile organic matter into rivers, has already been reported to increase $\mathrm{pCO}_{2}$ (Kempe, 1984). The significant relationships between (i) $\mathrm{N}_{2} \mathrm{O}, \mathrm{NH}_{4}{ }^{+}$and $\mathrm{NO}_{2}{ }^{-}$and (ii) $\mathrm{CO}_{2}$, oxygen and DOC we found in our study corroborated the importance of in-stream processes that are mainly supported by anthropogenic inputs via urban effluents (i.e., mineralization of organic matter, denitrification, nitrification and lower oxygen concentration in the lower Seine River). In African rivers, Borges et al. (2015b) reported similar net heterotrophic dynamics for these aquatic ecosystems based on the relationships between $\mathrm{pCO}_{2}, \mathrm{CH}_{4}$ and dissolved oxygen $\left(\mathrm{O}_{2}\right)$, despite lower domestic wastewater inputs in tropical systems, but with forested riparian zones and wetlands that also enriched the river in organic matter.

It is worth mentioning that only diffusive emissions of $\mathrm{CH} 4$ were taken into account, although $40 \%$ ebullition of indirect emissions could be added (Garnier et al., 2013). However taking the high contribution of $\mathrm{CO}_{2}$ emissions in the drainage network into account would not affect the overall results. 


\subsubsection{Direct $\mathrm{CO}_{2}, \mathrm{CH}_{4}, \mathrm{~N}_{2} \mathrm{O}$ emissions from the Seine basin: agricultural and nonagricultural emissions}

Indirect GHG emissions from the hydrographic network accounted for 3.7\% of the total emissions, $23.3 \%$ being linked to agricultural activities and land use, $73.0 \%$ to nonagricultural uses (dominated by the urban sources in the Ile-de-France region).

Such a high proportion of nonagricultural GHG (heating, transport, energy and industry) from a very highly populated area (Ile-de-France with $12 \mathrm{M}$ inhab. vs. $16 \mathrm{M}$ inhab. for the entire Seine basin) is not surprising, and is in line with results reported for other large cities (Pataki et al., 2006). Although human respiration, which accounts for $10 \%$ of the total $\left(1 \mathrm{~kg} \mathrm{CO}_{2}\right.$ inhab ${ }^{-1} \mathrm{yr}^{-1}$, Prairie and Duarte, 2007), was included in the estimates as the measurements came from tower fluxes and atmospheric inversion (Breón et al., 2015; Wu et al., 2016), we did not subtract this flux. Urban agriculture and many other small sectors (See Table 1-1A, $\mathrm{Wu}$ et al., 2016), reported to account for $2.7 \%$, were not taken into account either. On the whole, according to Bréon et al. (2015), we can consider that in megacities such as Paris and it conurbation, net $\mathrm{CO}_{2}$ fluxes are dominated by fossil fuel emissions. These Ile-de-France fuel emissions are hypothesized to account for $12 \%$ of those from France as a whole (Boden et al., 2013).

Among the $23.3 \%$ of agricultural emissions, the highest proportion $(51 \%)$ was related to $\mathrm{CH}_{4}$ although since the late 1970s, livestock has been confined to the periphery of the Seine basin (Mignolet et al., 2007). $\mathrm{N}_{2} \mathrm{O}$ emissions accounted for $33 \%$ and $\mathrm{CO}_{2}$ for $16 \%$ of agricultural emissions. Whereas intensive cereal cropping contributed to $\mathrm{N}_{2} \mathrm{O}$ direct emissions though fertilization (Bouwman, 1996b; Cayuela et al., 2017), it also contributes to $\mathrm{CO}_{2}$ emissions linked to the manufacture of fertilizers and direct fuel consumption for the cultivation of the $35,000 \mathrm{~km}^{2}$ basin (Garnier et al., 2013).

Finally, for a highly human-populated basin such as the Seine, the riverine emissions accounted for only a small fraction (3.7\%) of total emissions. However, cities have mitigation options, such as green technologies, and changes in lifestyle (drastic reduction in fossil energy consumption for individual vehicles, better insulation of buildings, etc.) as well as structural changes in agricultural production (e.g., more organic agriculture without mineral fertilizers, 
carbon storage) may alter the proportions of emissions currently estimated to be dominated by $\mathrm{CO}_{2}$ emissions.

\subsection{Conclusion}

In this study, we estimated emissions of greenhouse gases from the Seine hydrosystem characterized by a high population rate and intensive agriculture. At the regional scale of the Seine basin, $\mathrm{CO}_{2}$ emissions (in $\mathrm{CO}_{2}$ eq.) accounted for 6.4 and 9.5 times the amount of $\mathrm{CH}_{4}$ and $\mathrm{N}_{2} \mathrm{O}$ emissions, respectively, in good agreement with the $\sim 10$ times found at the global scale.

We showed that the hydrological drainage network of the Seine River was oversaturated in GHGs $\left(\mathrm{CO}_{2}, \mathrm{CH}_{4}\right.$, and $\left.\mathrm{N}_{2} \mathrm{O}\right)$ with respect to their atmospheric concentrations. GHG emissions from the Seine hydrosystem accounted for only $3.7 \%$ of the total GHGs emitted from the basin as a whole. GHG emissions from the hydrosystem were also dominated by $\mathrm{CO}_{2}$ emissions $(95.3 \%$ of the $3.7 \%$ ) and were interpreted as controlled by soil leaching and groundwater discharges in small SOs and by wastewater effluents along the main stem of the Seine River. Of the $73 \%$ of the GHG emissions originating from the nonagricultural sector, $\mathrm{CO}_{2}$ emissions contributed $98 \%$, and most came from the Ile-de-France region. For the agricultural sector, the $23.3 \%$ of GHG emissions mainly comprised $\mathrm{CH}_{4}$ and $\mathrm{N}_{2} \mathrm{O}-51 \%$ and $33 \%$, respectively - while $\mathrm{CO}_{2}$ emissions accounted for only $16 \%$.

In the future, modeling different scenarios for climate change or changes in anthropic pressure in the Seine basin (including agricultural practices and energy consumption) could enable us to propose actions to minimize the emissions of these greenhouse gases. 


\subsection{Annex}

\subsubsection{Annex 1-1. Lithology (Albinet, 1967) and stream orders (Strahler,} $1952 ; 1957)$ in the Seine basin.

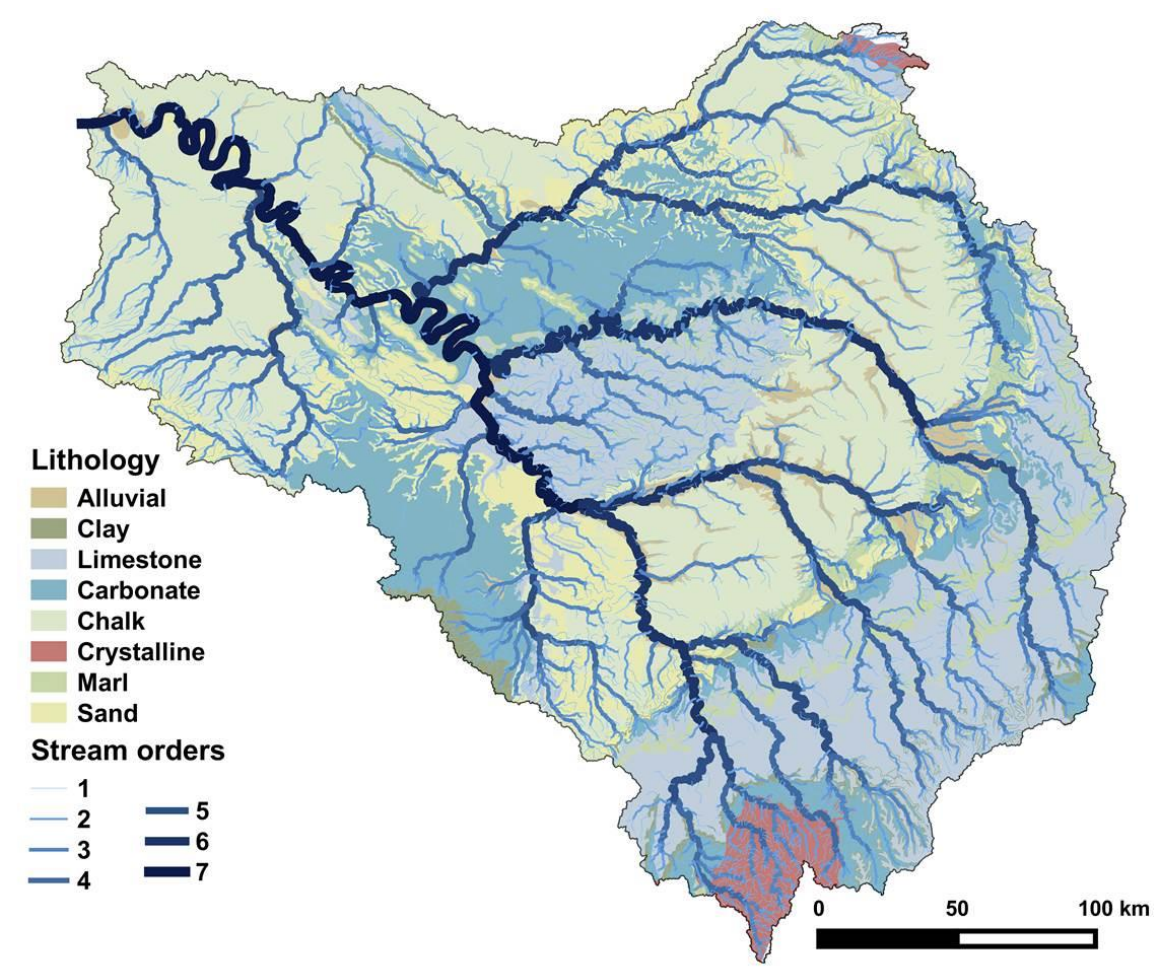

Fig. 9 Map of the lithology (Albinet, 1967) and stream orders (Strahler, 1952; 1957) in the Seine basin.

\subsubsection{Annex 1-2. Relationships between direct and indirect pCO2.}

A relationships was established between direct and indirect $\mathrm{pCO}_{2}$ measurements $(\mathrm{n}=108)$ for the Seine River basin (Marescaux et al., 2018) to reduce $\mathrm{pCO}_{2}$ indirect calculation bias (see Abril et al., 2015b).

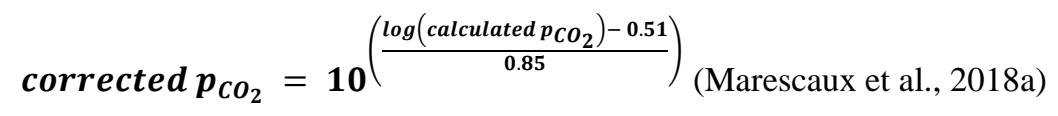

where calculated $\mathrm{pCO}_{2}$ is partial pressure of carbon dioxide (ppmv) calculated from $\mathrm{pH}$, total alkalinity, and water temperature using the CO2SYS software (Pierrot et al., 2006). The carbonate dissociation constants (K1 and K2) applied are from Millero, (1979) with zero salinity. $\mathrm{CO}_{2}$ solubility is from Weiss, (1974). 


\subsubsection{Annex 1-3 Spatial and seasonal variations in gas transfer velocities (k) of $\mathrm{CO} 2, \mathrm{CH} 4$ and $\mathrm{N} 2 \mathrm{O}$}

The difference in GHG concentrations between the atmosphere and water surfaces, and gas transfer velocities, control GHG emissions. Values of gas transfer velocities $(k)$ were higher for all GHGs for small Strahler order (SOs) than for high SOs (Fig. 2). Our $k$ calculations (Eq. 3 ) are directly related to slope, water velocity and water temperature. Consequently, $k$ trends according to Strahler order were in more in agreement with the steeper slopes of the small headwater streams than with those of the main streams. Seasonal patterns and gas transfer velocity values were similar for $\mathrm{CO}_{2}$ and $\mathrm{N}_{2} \mathrm{O}$, with higher $k$ in winter for small SOs than in summer, while the opposite patterns were observed for SOs 5-7. This resulted from the increase in water flow and water velocity in winter that affected $k$ values more strongly in small SOs than in main streams, whereas in summer, higher water temperatures led to higher $k$ in higher SOs than upstream. However, the $k$ of $\mathrm{CH}_{4}$ showed a different pattern with lower $k$ in summer whatever the SO. Indeed, $k$ depends on water temperature sensitivities of the Schmidt number of the different gases.
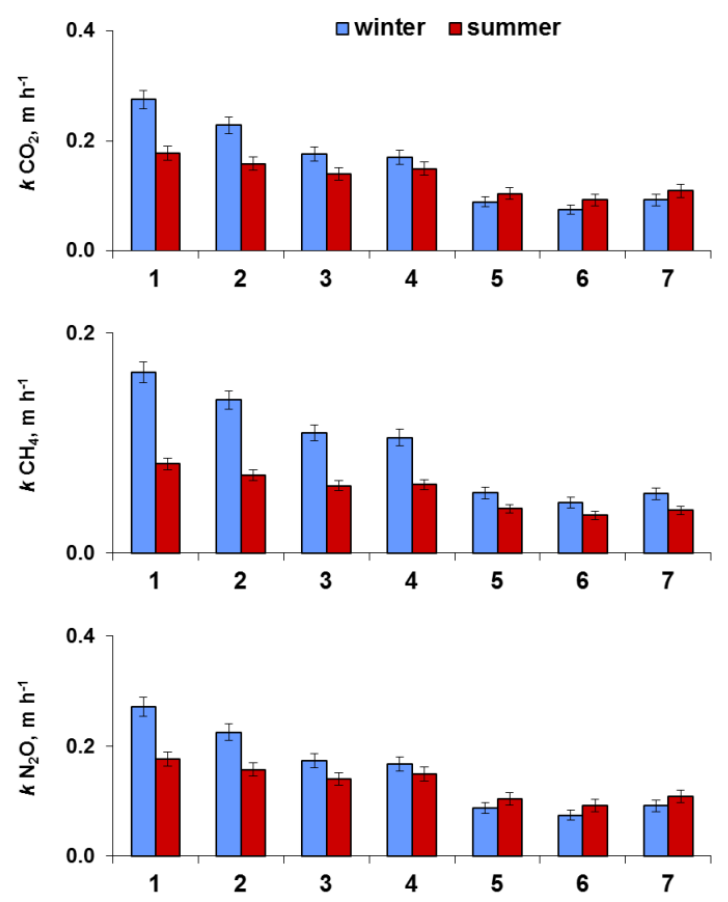
Fig. 10 Gas transfer velocity for $\mathrm{CO} 2, \mathrm{CH} 4, \mathrm{~N} 2 \mathrm{O}$ calculated according to the fifth equation in table 2 in Raymond et al. (2012) as a function of stream order (SO) in the Seine basin in winter (blue) and in summer (red). Whiskers are standard deviations between observed GHG concentrations

\subsubsection{Annex 1-4 Greenhouse gas concentrations ([GHG]) and fluxes (fGHG) with associated standard deviations and $95 \%$ confidence intervals averaged by season and by stream order.}

\begin{tabular}{|c|c|c|c|c|c|c|c|c|c|c|c|}
\hline & & & \multirow[t]{2}{*}{ [GHG] } & \multirow[t]{2}{*}{$\mathrm{sd}$} & \multicolumn{2}{|c|}{$95 \%$ C.I. } & & \multirow[t]{2}{*}{ fGHG } & \multirow[t]{2}{*}{$\mathrm{sd}$} & \multicolumn{2}{|c|}{ 95\% C.I. } \\
\hline & & & & & $<$ & $>$ & & & & $<$ & $>$ \\
\hline \multirow{14}{*}{ 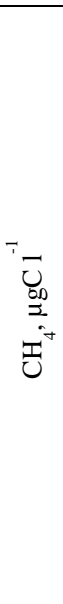 } & \multirow{7}{*}{$\begin{array}{l}\bar{\Xi} \\
\text { : } \\
\text { ह }\end{array}$} & 1 & 0.63 & 0.15 & 0.32 & 0.94 & \multirow{14}{*}{ 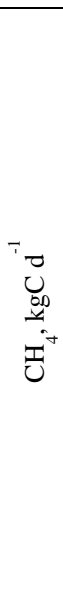 } & 34 & 9 & 16 & 52 \\
\hline & & 2 & 1.74 & 0.34 & 1.07 & 2.42 & & 78 & 16 & 45 & 111 \\
\hline & & 3 & 1.47 & 0.37 & 0.74 & 2.21 & & 64 & 17 & 29 & 98 \\
\hline & & 4 & 2.25 & 0.20 & 1.85 & 2.65 & & 102 & 12 & 78 & 126 \\
\hline & & 5 & 1.20 & 0.17 & 0.87 & 1.53 & & 49 & 8 & 32 & 66 \\
\hline & & 6 & 1.43 & 0.13 & 1.17 & 1.69 & & 56 & 8 & 40 & 73 \\
\hline & & 7 & 3.47 & 0.36 & 2.76 & 4.18 & & 171 & 25 & 121 & 221 \\
\hline & \multirow{7}{*}{$\stackrel{\overrightarrow{0}}{3}$} & 1 & 0.60 & 0.09 & 0.43 & 0.78 & & 65 & 11 & 44 & 87 \\
\hline & & 2 & 0.81 & 0.15 & 0.51 & 1.12 & & 68 & 14 & 40 & 97 \\
\hline & & 3 & 0.75 & 0.08 & 0.59 & 0.90 & & 55 & 7 & 41 & 69 \\
\hline & & 4 & 1.03 & 0.22 & 0.60 & 1.46 & & 77 & 18 & 41 & 113 \\
\hline & & 5 & 0.45 & 0.09 & 0.26 & 0.64 & & 22 & 6 & 11 & 34 \\
\hline & & 6 & 0.88 & 0.09 & 0.71 & 1.06 & & 45 & 7 & 32 & 59 \\
\hline & & 7 & 1.51 & 0.34 & 0.82 & 2.18 & & 100 & 26 & 48 & 152 \\
\hline \multirow{14}{*}{$\begin{array}{c}\bar{z} \\
z_{00} \\
z \\
0 \\
0 \\
z_{1}^{N} \\
z\end{array}$} & \multirow{7}{*}{$\begin{array}{l}\bar{\varpi} \\
\text { : } \\
\text { ह }\end{array}$} & 1 & 1.22 & 0.18 & 0.86 & 1.58 & \multirow{14}{*}{ 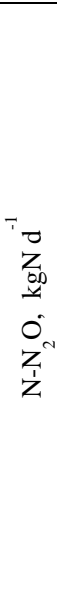 } & 117 & 26 & 66 & 168 \\
\hline & & 2 & 0.79 & 0.12 & 0.55 & 1.03 & & 51 & 13 & 24 & 78 \\
\hline & & 3 & 0.55 & 0.05 & 0.45 & 0.64 & & 27 & 7 & 13 & 41 \\
\hline & & 4 & 0.54 & 0.06 & 0.41 & 0.66 & & 30 & 9 & 12 & 48 \\
\hline & & 5 & 0.50 & 0.04 & 0.42 & 0.57 & & 27 & 7 & 12 & 41 \\
\hline & & 6 & 0.75 & 0.11 & 0.52 & 0.98 & & 56 & 16 & 24 & 89 \\
\hline & & 7 & 3.10 & 0.26 & 2.57 & 3.63 & & 400 & 61 & 279 & 521 \\
\hline & \multirow{7}{*}{ 离 } & 1 & 1.65 & 0.29 & 1.08 & 2.23 & & 250 & 59 & 131 & 368 \\
\hline & & 2 & 0.59 & 0.05 & 0.49 & 0.69 & & 31 & 9 & 13 & 49 \\
\hline & & 3 & 0.61 & 0.06 & 0.48 & 0.73 & & 29 & 9 & 11 & 48 \\
\hline & & 4 & 0.53 & 0.04 & 0.44 & 0.62 & & 20 & 7 & 5 & 35 \\
\hline & & 5 & 0.96 & 0.46 & 0.05 & 1.87 & & 53 & 42 & -32 & 138 \\
\hline & & 6 & 0.56 & 0.13 & 0.31 & 0.81 & & 16 & 12 & -8 & 40 \\
\hline & & 7 & 2.07 & 0.27 & 1.53 & 2.62 & & 202 & 43 & 116 & 287 \\
\hline \multirow{11}{*}{$\begin{array}{l}\overline{U_{0}} \\
\vec{Z} \\
0^{n}\end{array}$} & \multirow{7}{*}{$\begin{array}{l}\bar{\varpi} \\
\text { : } \\
\text { : }\end{array}$} & 1 & 3449 & 112 & 225 & 225 & \multirow{11}{*}{ 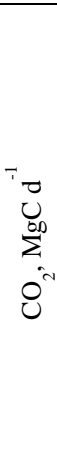 } & 351 & 21 & 310 & 661 \\
\hline & & 2 & 2114 & 53 & 107 & 106 & & 191 & 11 & 168 & 360 \\
\hline & & 3 & 1959 & 51 & 101 & 102 & & 175 & 11 & 152 & 327 \\
\hline & & 4 & 1548 & 39 & 79 & 79 & & 145 & 9 & 127 & 272 \\
\hline & & 5 & 1465 & 37 & 73 & 73 & & 130 & 11 & 108 & 238 \\
\hline & & 6 & 1731 & 52 & 104 & 103 & & 162 & 16 & 130 & 293 \\
\hline & & 7 & 2292 & 57 & 114 & 114 & & 287 & 24 & 238 & 525 \\
\hline & \multirow{4}{*}{ 离 } & 1 & 2168 & 72 & 144 & 144 & & 545 & 29 & 487 & 1032 \\
\hline & & 2 & 2410 & 67 & 134 & 134 & & 321 & 16 & 288 & 609 \\
\hline & & 3 & 2095 & 56 & 112 & 110 & & 236 & 13 & 211 & 447 \\
\hline & & 4 & 1633 & 43 & 86 & 86 & & 173 & 10 & 154 & 328 \\
\hline
\end{tabular}




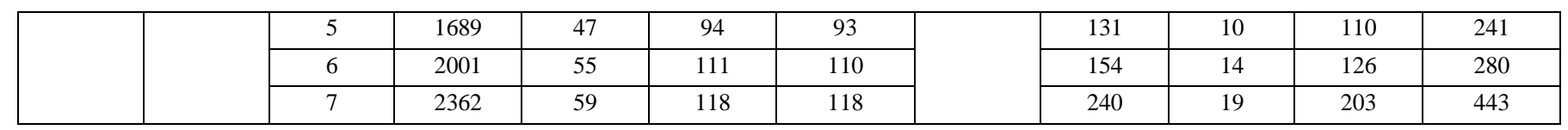

1.6.5. Annex 1-5 Results of the statistical differences between mean of greenhouse gas concentrations by stream order.

\begin{tabular}{|c|c|c|c|c|c|c|c|c|}
\hline & & \multicolumn{7}{|c|}{ Stream orders } \\
\hline & $\mathrm{CO}_{2}$ & 1 & 2 & 3 & 4 & 5 & 6 & 7 \\
\hline \multirow{23}{*}{ 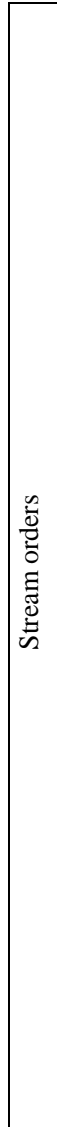 } & 1 & & $\mathrm{p}<0.05^{*}$ & $\mathrm{p}<0.05^{*}$ & $\mathrm{p}<0.05^{*}$ & $\mathrm{p}<0.05^{*}$ & $\mathrm{p}<0.05^{*}$ & $\mathrm{p}<0.05^{*}$ \\
\hline & 2 & & & $\mathrm{p}<0.05^{*}$ & $\mathrm{p}<0.05^{*}$ & $\mathrm{p}<0.05^{*}$ & $\mathrm{p}<0.05^{*}$ & $p>0.05$ \\
\hline & 3 & & & & $p<0.05^{*}$ & $\mathrm{p}<0.05^{*}$ & $p>0.05$ & $\mathrm{p}<0.05^{*}$ \\
\hline & 4 & & & & & $\mathrm{p}>0.05$ & $\mathrm{p}<0.05^{*}$ & $\mathrm{p}<0.05^{*}$ \\
\hline & 5 & & & & & & $\mathrm{p}<0.05^{*}$ & $\mathrm{p}<0.05^{*}$ \\
\hline & 6 & & & & & & & $\mathrm{p}<0.05^{*}$ \\
\hline & 7 & & & & & & & \\
\hline & $\mathrm{CH}_{4}$ & 1 & 2 & 3 & 4 & 5 & 6 & 7 \\
\hline & 1 & & $p>0.05$ & $\mathrm{p}<0.05^{*}$ & $p<0.05^{*}$ & $\mathrm{p}<0.05^{*}$ & $p<0.05^{*}$ & $\mathrm{p}<0.05^{*}$ \\
\hline & 2 & & & $p>0.05$ & $\mathrm{p}>0.05$ & $p>0.05$ & $\mathrm{p}>0.05$ & $\mathrm{p}<0.05^{*}$ \\
\hline & 3 & & & & $\mathrm{p}<0.05^{*}$ & $p>0.05$ & $p>0.05$ & $\mathrm{p}<0.05^{*}$ \\
\hline & 4 & & & & & $p>0.05$ & $p>0.05$ & $\mathrm{p}<0.05^{*}$ \\
\hline & 5 & & & & & & $p>0.05$ & $\mathrm{p}<0.05^{*}$ \\
\hline & 6 & & & & & & & $\mathrm{p}<0.05^{*}$ \\
\hline & 7 & & & & & & & \\
\hline & $\mathrm{N}_{2} \mathrm{O}$ & 1 & 2 & 3 & 4 & 5 & 6 & 7 \\
\hline & 1 & & $\mathrm{p}<0.05^{*}$ & $\mathrm{p}<0.05^{*}$ & $\mathrm{p}<0.05^{*}$ & $\mathrm{p}<0.05^{*}$ & $\mathrm{p}<0.05^{*}$ & $\mathrm{p}<0.05^{*}$ \\
\hline & 2 & & & $\mathrm{p}>0.05$ & $\mathrm{p}>0.05$ & $\mathrm{p}>0.05$ & $\mathrm{p}>0.05$ & $\mathrm{p}<0.05^{*}$ \\
\hline & 3 & & & & $p>0.05$ & $p>0.05$ & $\mathrm{p}>0.05$ & $\mathrm{p}<0.05^{*}$ \\
\hline & 4 & & & & & $\mathrm{p}>0.05$ & $\mathrm{p}<0.05^{*}$ & $\mathrm{p}<0.05^{*}$ \\
\hline & 5 & & & & & & $p>0.05$ & $\mathrm{p}<0.05^{*}$ \\
\hline & 6 & & & & & & & $\mathrm{p}<0.05^{*}$ \\
\hline & 7 & & & & & & & \\
\hline
\end{tabular}


1.6.6. Annex 1-6 Exact locations, mean and standard deviations of water quality parameters (chlorophyll a (Chl. a), total alkalinity, pH, dissolved oxygen (O2), and dissolved silica (DSi)) of the sampling stations located along the main stem of the basin.

\begin{tabular}{|c|c|c|c|c|c|c|c|c|c|c|c|c|c|c|}
\hline \multirow[b]{2}{*}{ Name of the sampling station } & \multirow{2}{*}{ Coordinates (EPSG 3857) } & \multirow{2}{*}{$\begin{array}{c}\mathrm{km} \\
(\text { Paris }=0)\end{array}$} & \multicolumn{2}{|c|}{ Chl. a $(\mu \mathrm{g} / \mathrm{l})$} & \multicolumn{2}{|c|}{$\begin{array}{l}\text { Water temperature } \\
\qquad\left({ }^{\circ} \mathrm{C}\right)\end{array}$} & \multicolumn{2}{|c|}{$\begin{array}{l}\text { Alkalinity } \\
\left(\text { mmole }^{-1}\right)\end{array}$} & \multicolumn{2}{|c|}{$\mathrm{pH}(-)$} & \multicolumn{2}{|c|}{$\mathrm{O}_{2}\left(\mathrm{mg} \mathrm{l}^{-1}\right)$} & \multicolumn{2}{|c|}{$\mathrm{DSi}\left(\mathrm{mg} \mathrm{l}^{-1}\right)$} \\
\hline & & & mean & $S D$ & mean & $S D$ & mean & $S D$ & mean & $S D$ & mean & $S D$ & mean & $S D$ \\
\hline Tancarville & $49^{\circ} 28^{\prime} 21.2^{\prime \prime} \mathrm{N} 0^{\circ} 27^{\prime} 51.5^{\prime \prime} \mathrm{E}$ & 337.00 & 33.20 & 22.18 & 17.05 & 2.4 & 4.17 & 0.42 & 8.09 & 0.18 & 7.41 & 0.74 & 3.31 & 0.90 \\
\hline Caudebec & $49^{\circ} 31^{\prime} 13.0^{\prime \prime} \mathrm{N} 0^{\circ} 44^{\prime} 50.1^{\prime \prime} \mathrm{E}$ & 310.50 & 14.22 & 10.05 & 17.73 & 2.0 & 4.14 & 0.41 & 8.05 & 0.21 & 7.48 & 0.71 & 3.07 & 1.10 \\
\hline Duclair & $49^{\circ} 28^{\prime} 47.3^{\prime \prime} \mathrm{N} 0^{\circ} 52^{\prime} 34.0^{\prime \prime} \mathrm{E}$ & 278.00 & 11.63 & 12.30 & 17.61 & 2.5 & 4.05 & 0.51 & 7.96 & 0.21 & 7.22 & 1.09 & 3.06 & 1.24 \\
\hline Bouille & $49^{\circ} 21^{\prime} 07.8^{\prime \prime} \mathrm{N} 0^{\circ} 56^{\prime} 03.6^{\prime \prime} \mathrm{E}$ & 259.70 & 12.20 & 14.17 & 17.88 & 2.3 & 3.99 & 0.66 & 7.94 & 0.18 & 7.14 & 0.80 & 2.97 & 1.32 \\
\hline Bas Dock & $49^{\circ} 266^{\prime} 36.9^{\prime \prime} \mathrm{N} 1^{\circ} 03^{\prime} 51.9^{\prime \prime} \mathrm{E}$ & 251.30 & 28.06 & 64.35 & 17.75 & 2.4 & 4.06 & 0.65 & 8.11 & 0.40 & 7.75 & 0.93 & 3.23 & 1.27 \\
\hline Oissel & $49^{\circ} 20^{\prime} 13.8^{\prime \prime} \mathrm{N} 1^{\circ} 05^{\prime} 36.4^{\prime \prime} \mathrm{E}$ & 229.40 & 24.53 & 50.89 & 18.00 & 2.3 & 4.01 & 0.61 & 8.02 & 0.23 & 8.20 & 0.83 & 2.83 & 1.39 \\
\hline Elbeuf & $49^{\circ} 17^{\prime} 36.9^{\prime \prime} \mathrm{N} 1^{\circ} 00^{\prime} 35.0^{\prime \prime} \mathrm{E}$ & 218.97 & 26.59 & 51.02 & 18.00 & 2.4 & 3.95 & 0.65 & 8.03 & 0.24 & 8.56 & 1.09 & 2.88 & 1.33 \\
\hline Poses & $49^{\circ} 18^{\prime} 35.9^{\prime \prime} \mathrm{N} 1^{\circ} 14^{\prime} 10.9^{\prime \prime} \mathrm{E}$ & 202.00 & 21.57 & 42.48 & 18.26 & 2.5 & 3.99 & 0.52 & 7.98 & 0.23 & 8.44 & 1.40 & 2.78 & 1.34 \\
\hline Vernon & $49^{\circ} 05^{\prime} 44.9^{\prime \prime} \mathrm{N} 1^{\circ} 29^{\prime} 15.9^{\prime \prime} \mathrm{E}$ & 150.00 & 15.76 & 31.64 & 17.99 & 2.9 & 3.90 & 0.66 & 7.93 & 0.24 & 8.13 & 0.57 & 2.78 & 1.29 \\
\hline Porcheville & $48^{\circ} 57^{\prime} 59.4^{\prime \prime} \mathrm{N} 1^{\circ} 46^{\prime} 35.3^{\prime \prime E}$ & 101.00 & 8.39 & 10.53 & 17.96 & 2.8 & 4.05 & 0.47 & 7.88 & 0.26 & 7.23 & 0.87 & 2.80 & 1.24 \\
\hline Poissy & $48^{\circ} 56^{\prime} 12.3^{\prime \prime} \mathrm{N} 2^{\circ} 02^{\prime} 19.6^{\prime \prime} \mathrm{E}$ & 76.00 & 6.14 & 6.54 & 17.85 & 2.9 & 4.06 & 0.45 & 7.84 & 0.19 & 7.72 & 0.99 & 2.86 & 1.32 \\
\hline Conflans & $48^{\circ} 59^{\prime} 19.2^{\prime \prime} \mathrm{N} 2^{\circ} 04^{\prime} 55.2^{\prime \prime} \mathrm{E}$ & 70.00 & 3.51 & 3.33 & 18.24 & 2.9 & 3.68 & 0.42 & 7.85 & 0.21 & 7.12 & 1.28 & 2.52 & 1.16 \\
\hline Maison Laffite & $48^{\circ} 56^{\prime} 41.1^{\prime \prime} \mathrm{N} 2^{\circ} 09^{\prime} 30.7^{\prime \prime E}$ & 48.00 & 4.57 & 3.72 & 18.12 & 3.0 & 3.72 & 0.46 & 8.05 & 0.39 & 7.43 & 1.01 & 2.25 & 1.11 \\
\hline Saint Maurice & $48^{\circ} 49^{\prime} 00.4^{\prime \prime} \mathrm{N} 2^{\circ} 25^{\prime} 11.9^{\prime \prime} \mathrm{E}$ & 0.00 & 19.58 & 52.80 & 17.50 & 3.2 & 4.18 & 0.39 & 8.17 & 0.26 & 9.52 & 2.16 & 2.25 & 1.11 \\
\hline Neuilly sur Marne & $48^{\circ} 51^{\prime} 13.0^{\prime \prime} \mathrm{N} 2^{\circ} 31^{\prime} 57.9^{\prime \prime} \mathrm{E}$ & -30.00 & 10.15 & 19.12 & 17.43 & 2.9 & 4.29 & 0.39 & 8.17 & 0.21 & 8.94 & 1.50 & 2.32 & 1.19 \\
\hline Annet & $48^{\circ} 54^{\prime} 59.0^{\prime \prime} \mathrm{N} 2^{\circ} 43^{\prime} 08.1^{\prime \prime E}$ & -50.00 & 9.19 & 16.06 & 17.18 & 2.8 & 4.31 & 0.38 & 8.17 & 0.17 & 8.97 & 1.11 & 2.22 & 1.10 \\
\hline Sammeron & $48^{\circ} 58^{\prime} 10.8^{\prime \prime} \mathrm{N} 3^{\circ} 19^{\prime} 15.0^{\prime \prime} \mathrm{E}$ & -120.00 & 6.80 & 8.53 & 17.16 & 3.1 & 3.97 & 0.39 & 8.16 & 0.17 & 8.89 & 0.84 & 1.82 & 0.85 \\
\hline Saulchery (Nogent l'Artaud) & $49^{\circ} 04^{\prime} 31.7^{\prime \prime} \mathrm{N} 3^{\circ} 38^{\prime} 12.5^{\prime \prime} \mathrm{E}$ & -150.00 & 4.76 & 4.49 & 17.17 & 3.0 & 3.93 & 0.35 & 8.12 & 0.30 & 8.64 & 0.97 & 1.65 & 0.76 \\
\hline Dormans & $48^{\circ} 59^{\prime} 43.0^{\prime \prime} \mathrm{N} 4^{\circ} 14^{\prime} 38.1^{\prime \prime E}$ & -180.00 & 4.68 & 3.48 & 17.16 & 3.3 & 3.69 & 0.45 & 8.11 & 0.26 & 8.58 & 0.74 & 1.44 & 0.59 \\
\hline Matougues & $48^{\circ} 37^{\prime 20.9 " N} 4^{\circ} 42^{\prime} 01.9^{\prime \prime} \mathrm{E}$ & -260.00 & 3.12 & 1.53 & 16.49 & 3.3 & 3.62 & 0.53 & 8.04 & 0.17 & 8.60 & 0.97 & 1.28 & 0.62 \\
\hline Moncetz l'Abbaye & $48^{\circ} 38^{\prime} 49.0^{\prime \prime} \mathrm{N} 4^{\circ} 39^{\prime} 12.7^{\prime \prime E}$ & -335.00 & 5.06 & 3.36 & 16.23 & 3.7 & 3.47 & 0.59 & 8.12 & 0.18 & 8.95 & 1.22 & 0.98 & 0.56 \\
\hline Arrigny & 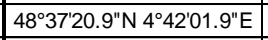 & -337.00 & 7.15 & 6.95 & 16.30 & 4.0 & 3.34 & 0.79 & 8.03 & 0.52 & 8.63 & 1.70 & 1.08 & 0.59 \\
\hline Larzicourt & $48^{\circ} 37^{\prime} 47.2^{\prime \prime} \mathrm{N} 4^{\circ} 42^{\prime} 34.0^{\prime \prime} \mathrm{E}$ & -340.00 & 5.83 & 3.96 & 15.11 & 2.7 & 4.17 & 0.43 & 8.15 & 0.39 & 8.69 & 1.46 & 1.21 & 0.81 \\
\hline
\end{tabular}




\section{Acknowledgements}

The C-CASCADES (https://c-cascades.ulb.ac.be/) project of which this study was a part, received funding from the European Union's Horizon 2020 research and innovation programme under the Marie Sklodowska-Curie grant agreement No. 643052. Audrey Marescaux benefitted from a PhD grant. The PIREN-Seine programme and the HydroGES project are also greatly acknowledged for their support. Many thanks are due to Abdelkader Azougui, Sébastien Bosc, Anunciacion Martinez Serrano, and Benjamin Mercier for their kind participation in the fieldwork and for their assistance with chemical analyses in the lab. Goulven Laruelle is also acknowledged for his help with statistical analyses. Vincent Thieu (assistant-professor at the University Pierre and Marie Curie, Paris) and Josette Garnier (Research Director at the CNRS, Centre National de la Recherche Scientifique, France) are co-supervisors of the $\mathrm{PhD}$ candidate. We thank the four anonymous reviewers for their constructive comments.

The datasets generated during the current study are available from the corresponding author on reasonable request (Audrey.marescaux@sorbonne-universite.fr)

\section{Affiliations}

Sorbonne Universités, Université Pierre et Marie Curie, Centre National de la Recherche Scientifique, Institut Pierre Simon Laplace, UMR 7619 METIS, Paris, France

\section{Author contribution statement}

All the authors contributed to the design of the study. JG and VT are co-supervisors of the $\mathrm{PhD}$. $\mathrm{AM}$ participated as a $\mathrm{PhD}$ student in the field campaigns and chemical analyses in the laboratory. AM wrote the first draft of the manuscript, and all co-authors helped interpret the data and write the article.

Corresponding authors : Audrey Marescaux, Audrey.maresaux@ sorbonne-universite.fr

Competing interests : The authors declare no competing personal or financial interests.

\section{Data availability}


The datasets generated during the current study are available from the corresponding author on reasonable request 